\title{
DEVELOPING A NOVEL ENVIRONMENTAL ASSESSMENT MODEL FOR POWER GENERATION PLANTS
}

\author{
NDALA Y. MULONGO \& CLINTON AIGBAVBOA \\ Faculty of Engineering and the Built Environment, \\ University of Johannesburg, South Africa
}

\begin{abstract}
Environmental assessment is a concept that has been designed to facilitate the present generation to meet their needs without compromising the ability of future generations to meet their own needs as well. Thus, this concept has drawn significant attention from various scholars, researchers and industrial practitioners around the world over the past three decades. Life Cycle Environmental Assessment (LCEA) is a widely metric used to assess the potential ecological impacts, which can be caused by electricity generating supply systems or by other systems than power production plants. However, the current LCEA model is biased and ineffective. Because, its omits factors that are increasingly contributing to the ecological degradation. This study has identified the omitted factors through a critical analysis of a set of previous journal articles conducted in the energy sector. In light of this, this study has developed a novel LCEA framework addressing those blind spots. The framework developed in this study is holistic in nature including all the life cycle stages of a power supply system such as Extraction of the Raw Material (ERM), Transport of Raw Material (TRM), Conversion of Raw into Electricity (CRE), and Transmission and Distribution of Electricity (TDE) to the end users. The novel developed LCEA model has been tested and applied to nine power generation plants such as coal, gas, nuclear, biomass, geothermal, hydro, solar thermal, wind onshore and wind offshore. The results have demonstrated that of conventional technologies including coal, gas, and nuclear, coal energy generating source has got the highest life cycle greenhouse gas Grid Emission Factor (GEF) of $2866 \mathrm{~kg}$ $\mathrm{CO2e} / \mathrm{MWh}$, followed by gas with $728 \mathrm{~kg} \mathrm{CO2e} / \mathrm{MWh}$, and nuclear has got the least GEF of $35 \mathrm{~kg}$ $\mathrm{CO2e} / \mathrm{MWh}$. Whereas of renewable energy sources biomass has got the highest GEF of $1508 \mathrm{~kg}$ $\mathrm{CO2e} / \mathrm{MWh}$, followed by solar thermal with $46.6 \mathrm{~kg} \mathrm{CO2e/MWh}$, hydro $39 \mathrm{~kg} \mathrm{CO2e/MWh}$, wind offshore $25.25 \mathrm{~kg} \mathrm{CO2e} / \mathrm{MWh}$, wind onshore $10.1 \mathrm{~kg} \mathrm{CO2e} / \mathrm{MWh}$, and geothermal closes the ranking with $6.23 \mathrm{~kg} \mathrm{CO2e/MWh}$.
\end{abstract}

Keywords: environmental assessment, novel LCEA model, electricity generating supply systems, lifecycle greenhouse gas grid emission factor.

\section{Introduction}

Electricity production usually involves the combustion of fossil fuels, which gives rise to greenhouse gas (GHG) emissions. This latter has caused one of the major concern striking the 21 st century is the development of Sustainable Development (SD) whilst rising mankind welfare. Contemporary technology generally has controverting impacts over the concept of SD, as portrayed through the present power supply system. Low-priced, easily-available electrical energy is very important to various contemporary society 's most significant technologies and SD advances. Meanwhile, the immense mainstream of the global's electrical energy is produced by means of fossil fuels, which caused stern ecological burdens. Thus, any shift towards a sustainable, thriving future will necessitate resources of electrical energy, which can offer the benefits of current 's power production system whilst diminishing its harmful impacts. One possible solution to this situation is the extensive assessment of the three sustainability pillars (economic, environmental, and social) associated with electricity generating technologies. This will assist all stakeholders involved in decision making process to invest in technologies, which will make significant contribution to SD. Increasing the demand for power reinforces the necessity for reducing effects from electrical energy production per unit generated. Worldwide electrical energy generation grew at an annual average of 3.5\% from 2003 to 2013 (Hans and 
Anders, 1999; Hatice et al, 2016; Hiroki and Yue, 2017; Hondo, 2005; Hrayshat, 2009).

Forecasts have demonstrated that, in the present coal reliance is not lowered, coal-based power plants within emerging nations alone will generate more greenhouse gas emissions than the whole OECD energy sector in the year 2030 (Ishan and Pallav, 2017; Ivan et al, 2016; Janie and Anthony, 2017; Jelena et al, 2012). The effects of emerging countries working in achieving improved lifestyles, driving by inhabitants' increase can further upsurge the electrical energy usage rates. To achieve growing power supplies with negligible ecological effect, shift to the present electricity production practices are needed to take in augmented power efficiency as of fossil fuel burning technologies by introducing renewable energy sources into the market. However, fossil fuels electricity generating resources provide high reliability and low-priced. Therefore, cautious ecological assessment regarding each technology is required to manage upcoming investment and policy. In this paper, we assessed the sustainability of 9 power production, including coal, gas, nuclear, wind offshore, wind onshore, biomass, geothermal, solar thermal, hydro, on basis of the greenhouse gas Grid Emission Factor (GEF) is the total amount of GHGs emitted per unit of electricity generated for and distributed by an electricity grid, taking in account imports and exports of electricity from the interconnection with other grids. These emissions comprise methane $\left(\mathrm{CH}_{4}\right)$; carbon oxide $(\mathrm{CO})$; carbon dioxide $\left(\mathrm{CO}_{2}\right)$; mercury $(\mathrm{Hg})$; nitrous oxide $\left(\mathrm{N}_{2} \mathrm{O}\right)$; ammonia $\left(\mathrm{NH}_{3}\right)$; nitrogen oxide $(\mathrm{NOX})$; lead $(\mathrm{Pb})$; sulphur hexafluoride $\left(\mathrm{SF}_{6}\right)$; sulphur dioxide $\left(\mathrm{SO}_{2}\right)$; volatile organic compounds (VOC0. The GEF is typically expressed as t $\mathrm{CO} 2 \mathrm{e} / \mathrm{MWh} . \mathrm{CO} 2 \mathrm{e}$ is used to denote the inclusion of non- $\mathrm{CO} 2$ gases.

\section{Existing literatures}

The aim of any significant work is to bring significant contribution to the body of knowledge. In light of this, the present study identified gap in the existing literature through a thorough critical assessment of a set of previous studies that used Life Cycle Environmental Assessment (LCEA) tool to assess the environmental aspect of electricity generating technologies. It should be noted that the environmental system boundaries considered in those previous studies are also scrutinized. This section aims at scrutinizing all the studies that used only Life Cycle Assessment (LCA) tool to assess the environmental aspect of electricity generating technologies. It should be noted that the environmental system boundaries considered in these are also scrutinized.

Ning et al [1] carried out a sustainability study regarding the electricity sector in China. The focus was on thermal power, hydropower, solar PV, nuclear power, and wind power. The system boundaries considered here for the sustainability assessment comprised Extraction of Raw Material (ERM), Conversion of Raw Material into Electricity (CRE), and Transport and Distribution of Electricity (TDE). To this end, the sustainability of this study is not complete because the authors focused only on the environmental aspect ignoring two crucial sustainability pillars which are economic and social aspects. Additionally, the environmental assessment of power plants is naïve since the TRM was left out. Therefore, one should not fully rely on the results of this study. In light with this, the findings gathered by the authors show that there are discrepancies regarding Global Warming Potential (GWP) of those power plants. Particularly, thermal power release 19, 66, 123, and 164 times more emissions comparing to solar PV, hydro, wind, and nuclear power plants, separately. Furthermore, there are inconsistencies in the GWP about $1 \mathrm{kWh}$ of thermal power regarding different regions and national average. Lastly, the outcomes show that there are incongruities in the GWP of hybrid power concerning various regions. For example, the results show that Inner Mongolia and Qinghai have the largest and the smallest GWP for $1 \mathrm{kWh}$ of hybrid electricity supply, respectively.

Tonini and Thomas [4] conducted an environmental analysis of power sector in Denmark. The authors focused on fossil fuels, wind and biomass energy considering 2008 as the reference year, 
and energy scenarios for 2030 and 2050 were evaluated. To this end, the sustainability of this study is not complete because the authors focused only on the environmental aspect ignoring two crucial sustainability pillars which are economic and social aspects. Additionally, the environmental assessment of power plants is naïve since the ERM and TDE were left out. The findings of this study demonstrate that the life cycle GHG per PJ energy generated may be importantly lessen (from 68 to $17 \mathrm{Gg} \mathrm{CO} 2-\mathrm{eq} / \mathrm{PJ}$ ) by increasing the deployment of wind and residual biomass power plants. Energy crops for producing biofuels and the deployment of these biofuels for heavy terrestrial transport contribute significantly to the pollution of the environment in the 2050 scenarios, specially emissions generated from upstream due to land occupation, fertilizer use and nitrogen oxides emissions emitting during the TRM. Land used by energy crop production augmented to an array of 600-2100 $106 \mathrm{~m} 2 / \mathrm{PJ}$ depending on the quantity and kinds of energy crops introduced.

Turconi et al [32] conducted a critical assessment of 167 case studies. These studies focused on the LCA of power generating sources (coal, natural gas, oil, nuclear, biomass, hydroelectric, solar PV and wind. The authors aimed at determining extent of emission regarding GHG, nitrogen oxide, and sulphur dioxide associated with different technologies. However, the study conducted by these authors based on the critical appraisal of those 167 case studies does not add significant value to the field of sustainability. Because the sustainability frameworks of those studies are not comprehensive since they focused only on the environmental aspect leaving out two critical sustainability pillars which are economic and social aspects. In addition, the environmental analysis of those study including for Turconi et al [32] is biased since the TRM and TDE are ignored. The findings demonstrate that most of emissions are emitted during the operation of the plant and are generated by fossil fuel technologies. In contrast, fuel provision was the major contributor concerning biomass technologies ( $71 \%$ for GHG, 54\% for NOx and $61 \%$ for SO2) and nuclear power $(60 \%$ for GHG, $82 \%$ for NOx and $92 \%$ for SO2). The construction of infrastructures offered the contribute significantly for renewable energy sources. Therefore, this critical review shows that the inconsistency of current LCA outcomes for power production plants can give rise to contradictory decisions concerning the environmental impacts of implementing new technologies. in their works Rita et al [2] and Hans \& Anders [3] performed an environmental assessment of different electricity generating sources. The authors focused only on one aspect of sustainable development. Due to this blow, the results of this work should not have been fully relied on. As the authors missed to include other two critical aspects of sustainability, which are financial and social aspects of a power production plant. Fatemeh et al [25] conducted a critical literature review of previous LCA studies. However, as mentioned in the lines above that an -in-depth sustainable development evaluation takes into account three main components, thus, the results of this work should not be fully relied on. As the authors missed to include other two critical aspects of sustainability, which are financial and social aspects of a power production plant.

In light with the above studies, there are also studies such as Peng et al [5]; Ming et al [6]; Pehnt [7]; Pehnt et al [8]; Pehnt and Henkel [9]; and Onat and Bayar [10] conducted an environmental performance of nuclear power plants in China. However, their work did not meet the requirement for a complete sustainable development evaluation, which relies on three main components, thus, the results of this work should not been fully rely on. As the authors missed to include other two critical aspects of sustainability, which are financial and social aspects of a power production plant. Valentina et al [11] conducted a LCA study to assess the environmental sustainability of power generation from an Anaerobic Digestion (AD) unit employing a combination of dedicated energy crops, agrarian waste and livestock wastes as raw materials. The authors used $1 \mathrm{MJ}$ of electrical energy as the operational unit. System boundaries were from cradle to grave considering all the stages from agricultural of energy crops to biogas generation and its employment within a CHP to generate electricity. Though, the environmental analysis of this study is based on cradle to grave. 
Due to non-inclusion of economic and social aspects in the framework, therefore, one should not fully rely on the findings presented in this study in terms of sustainable development. Another bias is based on TDE, which is not included in the environmental assessment. The findings illustrate that the major hotspots are energy crops cultivation and the management of digestate, largely owing to both NOx and $\mathrm{CH} 4$ emissions, affecting Global Warming, Acidification, Marine and Freshwater Eutrophication.

Yemane et al [12] carried out an environmental analysis concerning three biomass-based options cases that characterised energy transition and transformation of power sector in Canada, with the dominant case of coal electrical energy generating source. This study treats the sustainability matter naively because it does not cover social aspect and also the environmental assessment include only the PRM phase ignoring three main phases ERM, TRM, and TDE. To this end, the findings collected concerning the biomass environmental life cycle demonstrated a significant improvement from 47 to $92 \%$ for global warming, 46 to $90 \%$ for mankind health, and 47 to $91 \%$ for environmental issues comparing to coal-fired power plant case. In contrast, the coal power production plant showed roughly $63-83 \%$ less life cycle cost impact than other options.

Sastre et al [15] conducted a sustainability assessment study of electricity in Spain. The aim of their study was to offer more accurate findings regarding LCA of electrical energy production from wheat straw grown by including certain factor ambiguity and erraticism in the inventories. Their findings demonstrate that most of the simulations electrical energy generated through the combustion of wheat straw biomass release very few GHG emissions and used up not as much of fossil energy than electrical energy produced by gas technology. But, their findings also revealed that only $58 \%$ of the simulations met the sustainability target of $60 \%$ GHG savings as recommended by the European Union (EU). Although, the results of this study shows a significant saving of GHG emissions of around 58\%, the sustainability analysis is still incomplete since economic and social aspects, which two fundamental sustainability aspects were ignored. Furthermore, the environmental assessment only considered the ERM and CRE stages ignoring other crucial life cycle stages. To this end, one should not fully rely on the results of this study because it does not meet the requirement of a holistic sustainability framework.

Santoyo-Castelazo et al [13] used LCA approach to assess the environmental sustainability of electricity generating sources in Mexico, where $79 \%$ of electricity is generated from fossil fuels, hydropower $13.5 \%$, geothermal $3 \%$ and wind $0.02 \%$ and $4.8 \%$ is produced by nuclear technology. The findings of this study show that $225 \mathrm{TWh}$ of electrical energy produced emit at least 129 million tonnes of $\mathrm{CO} 2$ eq. per annum, most of which $(87 \%)$ is because of the burning of fossil fuels. Whereas, hydropower, geothermal, wind and nuclear contribute only $1.1 \%$ to the overall CO2 eq. Despite this, the sustainability framework developed by Santoyo- Castelazo et al [13] is biased because it only focused on environmental aspect, thus, leaving out economic and social impacts of the power plants. Additionally, some important environmental indictors, such as ERM, TRM, and TDE.

Santoyo-Castelazo et al [14] develop a sustainability analysis model in order to decarbonise the power sector in Mexico. To this end, they focused on environmental impact of different power production plants up to 2050. In light with this, the covered 10 environmental issues, including global warming, resource and ozone layer shrinking, acidification, eutrophication, summer smog, human and ecotoxicity. According to Santoyo-Castelazo et al [14] based on the findings that they collected carrying on using fossil fuels to generate electricity can double the life cycle GHG emissions, albeit yearly electrical energy demand growth was lowered to $2.25 \%$ from the 2014 percentage of $2.8 \%$. Thus, they argued that changing from the employment of fossil fuel mix to a higher contribution of renewables $(55-86 \%$ ) and nuclear power (up to $30 \%$ ) can cause an 
important diminution of all ten life cycle issues comparing to the 2014 circumstances and up to an $80 \%$ decrease. However, this study does not also add substantial value to the field of sustainability. Because the sustainability framework developed concentrated only on the environmental aspect ignoring two critical sustainability pillars which are economic and social aspects. Additionally, the environmental analysis is not complete since the ERM, TRM, and TDE stages were not included in the framework.

Paul et al [16] assessed the impact of life cycle GHG emissions per MWh of electrical energy generated, this is based on a range of various power production plant for Australian electricity sector. They findings show that Liquefied natural gas does not emit a lot of GHG emission as black coal, however, the difference is minor for OCGT plant and for CSG. In accordance with their results traditional natural gas consumed within a traditional OCGT plant is roughly $38 \%$ less GHG intensive throughout its life cycle than black coal consumed in a sub-critical plant, per MWh of electrical energy generated. Paul et al (2012) point out that, if OCGT combustion is compared to the most efficient new ultra-supercritical coal-fired power, the difference narrows significantly. Coal seam gas LNG is roughly $13-20 \%$ more GHG intensive during its life cycle, on a like-forlike basis, than conventional LNG, and thus compares less favourably to coal than conventional LNG under all technology combinations. But, this study does not also add significant value to the field of sustainability. Since the sustainability framework developed is incomplete due to the fact that they authors considered only the environmental aspect disregarding two critical sustainability pillars which are economic and social aspects. Additionally, the environmental analysis is not complete since the ERM, TRM, and TDE stages were not included in the framework.

Andrew et al [18] applied LCA to a $3 \mathrm{~kW}$ hydro-power located in Thailand. The authors considered the cradle to grave assessment framework for the hydropower during a period of two decades, as well as all appropriate equipment, materials and transportation. Their findings demonstrate that when comparing small-scale hydropower plant with largescale hydropower plant. The former one has a greater environmentally impact per $\mathrm{kWh}$ of electricity generated and perform less well environmentally than latter one. However, the results show that hydropower unit used in this study produce better ecological and financial results than diesel generator and grid connection options. However, the framework developed in this study is biased and does not also add substantial value to the field of sustainability. since the authors considered only the environmental impact, thus, disregarding two critical sustainability pillars which are economic and social aspects. Additionally, the environmental analysis itself is not complete due to lack of the ERM, TRM, and TDE stages in the framework.

Oliveira et al [17] developed a LCA model to assess the impacts of the climate change, mankind toxicity, particulate matter formation, and fossil resource diminution. Various power plants mix were deployed to demonstrate cases where the designated technologies meet particular applications. Their findings show that the impacts renewable energy sources during the employment phase of the storage technologies is insignificant. Belgium electricity mix of 2011 was used as benchmark, the sodium sulphur battery is revealed to be the best performer for all the impacts assessed. With pumped hydro storage ranks at the second position. Considering infrastructure and end of life, the findings illustrate that battery systems have higher impacts due to lower number of cycles and life time energy. However, the framework developed in this study is biased and does not also add substantial value to the field of sustainability. Because the authors took only the environmental aspect into account, therefore, ignoring two significant sustainability aspects, which are financial and social aspects. In addition, the environmental analysis itself is not complete because it did not cover the ERM, TRM, and TDE stages in the framework.

Messagie et al [21] used LCA approach to assess the GWP per kWh of electricity generated for each hour on the year basis for power sector in Belgium. The authors believed that the 
environmental analysis would have enabled them to assess the impact of the electrical energy demand on the GHG emissions. the authors state that due to the LCA tool, the carbon dioxide equivalent content does not only reflect activities associated with the electricity generation in a power plant, however, including GHG emissions associated with the construction of the plant and the fuel supply chain. In their work Messagie et al [21] focused on nuclear, oil, coal, natural gas, bio-waste, blast furnace gas, wood, solar PV, hydro-power installations and wind power plants. However, the downside with this study is that it cannot fully be relied on since is messing critical information regarding some aspects of sustainability such as economic and social impacts. In addition, the environmental appraisal of those power production plant is not comprehensive because of lack of the TRM, and TDE stages in the analysis. The results of this work indicate that electricity produced through the wind and solar power plants is more carbon intensive than the electrical energy generated by thermal power plants, one possible explanation is because of the lower electricity output. The total average GWP per $\mathrm{kWh}$ was $0.184 \mathrm{~kg} \mathrm{CO} 2 \mathrm{eq} / \mathrm{kW} \mathrm{h}$. over the 2011 , the authors argued that this figure varies from a minimum of $0.102 \mathrm{~kg} \mathrm{CO} 2 \mathrm{eq} / \mathrm{kW} \mathrm{h}$ to a maximum of $0.262 \mathrm{~kg} \mathrm{CO} 2 \mathrm{eq} / \mathrm{kW}$ h depending on the timing.

Meier et al [20] investigated the sustainability of natural gas power plant for the electricity sector in United States. In their work Meier et al [20] viewed natural gas as a sustainable carbon-lowering measure. Their results indicate that important GHG emissions are emitted into the environment during the gas power plant's upstream, mostly over fuel- cycle operations. The authors tested two carbon- lowering measures making use of life-cycle emission rates developed for the United States power sector. Depending fully on new natural gas units for CSA compliance can necessitate a $600 \%$ growth in natural gas produced electrical energy and practically full shift of coal from the fuel mix. On the other hand, a $240 \%$ growth in nuclear or renewable energy sources achieve the same target with minimal coal usage. The authors concluded their work by arguing that their study illustrate that how disregarding life-cycle GHG, particularly those being generated in upstream of the gas power plant, can lead to flawed appraisal of supply side compliance options. However, there is an important gap in this study due to sustainability framework developed, which treats the sustainability issues naively. Because, the model is pure environmental, thus, it does not consider the impacts associated with economic and social aspects. Another prejudice to this study is that the environmental evaluation of the power plants leaves out some crucial stages of life cycle such as ERM, TRM, and TDE.

Changqing et al [19] used LCA approach to compare the environmental sustainability of biomass and coal-fired plant. The focus of the environmental analysis was on TRM, PRM, and TDE. His findings demonstrate that for each biomass based scenario, the driving elements polluting the environment comprise GHG emissions such as nitrogen oxides, phosphorus, mercury, and particulate matter. Additionally, $\mathrm{CO} 2$ produced from $\mathrm{CH} 4$ burning, road transport, and electrical energy use contribute significantly to the pollution of the environment. But, when comparing with coal-fired power plant, it generates important ecological benefits in most key categories with the exception of climate change and human toxicity. Hence, in accordance with the results biomass is not totally cleaner than fossil fuel. however, this study does not add much on sustainability field. Because of lack of economic and social impacts in the assessment and in the context of environmental analysis there ERM stage was not considered. Thus, this gag needs to be filled in order to have a comprehensive assessment.

Yuan et al [23] used LCA models to measure the extraction- to-wire GHG emissions and water usage per $\mathrm{kWh}$ generated through coal-fired plant and shale gas power plant in China. The outcomes illustrate that shifting from coal to shale gas and upgrading coal-based poer plants can create routes for a smaller amount of GHG and water consumption for power sector in China. Additionally, the GHG emissions generated from gas-fired plant turned around $530 \mathrm{gCO} 2 \mathrm{e} / \mathrm{kWh}$ that is $38-45 \%$ less than the current China's coal-based power plant. Moreover, the results show 
that Gas-fired CT plant has the least ETW water use estimated at $960 \mathrm{~g} / \mathrm{kWh}$, which is $34-60 \%$ lesser than China's current coal power plant. However, this study does not also add substantial value to the field of sustainability. Because the sustainability framework developed concentrated only on the environmental aspect ignoring two critical sustainability pillars which are economic and social aspects. Additionally, the environmental analysis is not complete since the TRM, and TDE stages were not included in the framework.

Yaw et al [24] conducted a critical review of 79 studies based on LCA of onshore and offshore winds, hydropower, wave and tidal energy, geothermal, solar PV, solar thermal, biomass, waste, and heat pumps. The results show that offshore wind had the least GHG emissions since its life cycle GHG emissions was estimated at $5.3-13 \mathrm{gCO} 2 \mathrm{eq} / \mathrm{kWh}$. The findings also revealed that GHG generated by fossil fuel heat and electricity are relatively higher compared to renewable energy sources without considering nuclear technology. In their work Yaw et al (2014) considered renewable energy sources, waste treatment and dedicated biomass technologies (DBTs) were found to potentially have high GHG emissions based on the feedstock, selected boundary and the inputs required for their production. Though, the authors have given insight regarding environmental assessment of different power plants, the sustainability appraisal itself is not complete since it is missing some crucial information regarding economic and social impacts. Furthermore, the environmental assessment did not consider some important life cycle stage, such as TRM, and TDE.

Manfred [22] reviewed a set of studies regarding environmental impact of nuclear technology. The results show that the GHG emissions emitted by nuclear power plants using the reactor of types LWR and HWR range from 0.1 and $0.3 \mathrm{kWh}$, and on average about $0.2 \mathrm{kWh}$ for every $\mathrm{kWh}$ of electrical energy produced. These energy intensities translate into GHG emissions for LWR and HWR ranging from 10 and 130g CO2- e/kWh, with an average of $65 \mathrm{~g} \mathrm{CO} 2-\mathrm{e} / \mathrm{kWh}$. Despite the fact these GHG emissions are expectedly lower than those of fossil technologies (typically 600 $1200 \mathrm{~g} \mathrm{CO} 2-\mathrm{e} / \mathrm{kWh}$ ), they are higher than reported figures for wind turbines and hydroelectricity (around 15-25 g CO2-e/kWh) and in the order of, or slightly lower than, solar PV or solar thermal power (around $90 \mathrm{~g} \mathrm{CO} 2-\mathrm{e} / \mathrm{kWh}$ ). However, the downside with this study is that it cannot fully be relied on since is messing critical information regarding some aspects of sustainability such as economic and social impacts. In addition, the environmental appraisal of those power production plant is not comprehensive because of lack of the ERM, TRM, and TDE stages in the analysis.

\section{Conceptional framework}

To commence with the critical appraisal of existing literature review on sustainability assessment of power generation plants, the ISI Web of Science database was used with 'sustainability in electricity sector"' used as keywords. The time frame was from 1997-2017. The search only focused on peer-reviewed articles published in English, falling under certain subject areas. The search resulted in 389 documents that were thoroughly scrutinised by means of a of titles and abstracts with the purpose of developing additional boundaries and eliminating incorrect and/or unrelated entries (screening phase). Throughout this phase, groups of inclusion and segregation standards were established, versus which individually every singly journal article was evaluated. Precisely, articles assessed are those, which clearly considers sustainability analysis frameworks developed for power generation plants, and those that used sustainability appraisal to processes or materials related to other industries than power sector considering either single, two or all three sustainability pillars (environmental, social, economic) whilst assessing sustainability. It should be pointed out that studies that did not meet these norms were not taken into account. This stage generated 183 studies focusing on power generation plants and 20 studies focusing on other industries that electricity sector, were judged to be important for additional thorough scrutiny. Afterward, in order to respond to the main goal of this study, which is of developing a new, 
integrated sustainability assessment framework for power generation plants, the 183 studies were labelled on the basis of a set of standards, involving the general type of sustainability analysis used, the lifecycle phases (i.e, extraction of raw material, transportation of raw material, conversion of raw material into electricity, transmission and distribution of electricity to endusers); sustainability pillars taken into account (i.e. environmental, economic, and social aspects), the type of indicators used to assess the economic, environmental, and social impacts of different power generation plants. The outcomes of the critical appraisal of literature review generated various conclusions, first and foremost in current decade there has been a significant growth regarding the number of articles published related to sustainability in the electricity industry. Renewable Sustainable Energy Reviews was most represented in the literature review, with 61 of the 183 journal articles, followed by Energy Policy with 52 articles, Journal of Cleaner Production ranks at the third position with 28 articles, Energy with 25 articles, Applied Energy 21, Sustainability 14, Energies 10, Technological Forecasting and Social Change 9, and Renewable Energy 7 articles. Whereas, the remaining of the appropriate journals were just about equally distributed with low frequency (1-6 articles). Furthermore, the results of literature survey revealed that $77 \%$ of studies performed in electricity sector focused separately either on economic, environmental, or social aspects of power plants, while 7\% attempted to combined only two aspects, and only $16 \%$ of the works attempted to incorporate all the three sustainability pillars into one framework. Supporting the idea that the electricity sector would benefit from a holistic and comprehensive framework for sustainability assessment. Based on the gap identified in the previous studies, this study as expanded the environmental analysis framework as per table 2 below. The environmental system boundaries considered in this study of each electricity generating source account for the cradle-to-grave. The boundaries include four lifecycle phases as presented in the table 2 below. It should be noted that geothermal, wind, water, solar, electricity producing sources do not require extraction neither transportation, thus they are not considered in these stages.

Table 2. Expanded environmental assessment framework

\begin{tabular}{|l|c|c|c|c|}
\cline { 2 - 5 } \multicolumn{1}{c|}{} & \multicolumn{4}{c|}{ Environmental system boundaries } \\
\hline Technologies & ERM & TRM & CRE & TDE \\
\hline Coal & $\times$ & $\times$ & $\times$ & $\times$ \\
\hline Gas & $\times$ & $\times$ & $\times$ & $\times$ \\
\hline Nuclear & $\times$ & $\times$ & $\times$ & $\times$ \\
\hline Biomass & $\times$ & $\times$ & $\times$ & $\times$ \\
\hline Wind offshore & & & $\times$ & $\times$ \\
\hline Wind onshore & & & $\times$ & $\times$ \\
\hline Geothermal & & & $\times$ & $\times$ \\
\hline Solar thermal & & & $\times$ & $\times$ \\
\hline Hydro & & & & $\times$ \\
\hline
\end{tabular}

\section{Research findings}

This section presents the data concerning each life cycle stage of the expanded model proposed for every type of power plant. Noted that the present data were gathered through a thorough critical analysis review of scientific articles. Keeping the length of the article in mind, there is no need to include all the references consulted. However, the reader can refer to those studies presented in section 2, table 1 above. 


\subsection{Environmental profile for coal power plant}

Table 3. Life cycle greenhouse gas emissions for coal power plant

\begin{tabular}{|l|c|c|c|c|c|}
\cline { 2 - 7 } \multicolumn{1}{c|}{} & \multicolumn{4}{c|}{ Coal Life Cycle Greenhouse Gases Emissions (kg/MWh) } \\
\hline \multicolumn{1}{c|}{ GHGs } & ERM & \multicolumn{1}{c|}{ TRM } & \multicolumn{1}{c|}{ CRE } & \multicolumn{1}{c|}{ TDE } & \multicolumn{1}{c|}{ Total } \\
\hline $\mathrm{CH}_{4}$ & $4.952 \mathrm{E}+00$ & $7.694 \mathrm{E}-02$ & $2.328 \mathrm{E}-01$ & $0.00 \mathrm{E}+00$ & $5.262 \mathrm{E}+00$ \\
\hline $\mathrm{CO}$ & $2.124 \mathrm{E}-01$ & $2.784 \mathrm{E}-01$ & $3.568 \mathrm{E}+01$ & $0.00 \mathrm{E}+00$ & $3.617 \mathrm{E}+01$ \\
\hline $\mathrm{CO}_{2}$ & $4.255 \mathrm{E}+02$ & $6.823 \mathrm{E}+01$ & $2.323 \mathrm{E}+03$ & $0.00 \mathrm{E}+00$ & $2.817 \mathrm{E}+03$ \\
\hline $\mathrm{Hg}$ & $3.759 \mathrm{E}-04$ & $6.218 \mathrm{E}-04$ & $4.862 \mathrm{E}-03$ & $0.00 \mathrm{E}+00$ & $5.859 \mathrm{E}-03$ \\
\hline $\mathrm{N}_{2} \mathrm{O}$ & $3.326 \mathrm{E}-03$ & $2.283 \mathrm{E}-03$ & $7.924 \mathrm{E}-01$ & $0.00 \mathrm{E}+00$ & $7.980 \mathrm{E}-01$ \\
\hline $\mathrm{NH}_{3}$ & $3.675 \mathrm{E}-03$ & $3.113 \mathrm{E}-02$ & $2.745 \mathrm{E}-02$ & $0.00 \mathrm{E}+00$ & $6.225 \mathrm{E}-02$ \\
\hline $\mathrm{NOx}$ & $2.784 \mathrm{E}-01$ & $2.517 \mathrm{E}-01$ & $2.473 \mathrm{E}+00$ & $0.00 \mathrm{E}+00$ & $3.003 \mathrm{E}+00$ \\
\hline $\mathrm{Pb}$ & $2.597 \mathrm{E}-03$ & $7.684 \mathrm{E}-04$ & $3.746 \mathrm{E}-02$ & $0.00 \mathrm{E}+00$ & $4.082 \mathrm{E}-02$ \\
\hline $\mathrm{SF}$ & $3.162 \mathrm{E}-02$ & $3.455 \mathrm{E}-04$ & $7.431 \mathrm{E}-02$ & $3.268 \mathrm{E}+00$ & $3.374 \mathrm{E}+00$ \\
\hline $\mathrm{SOx}$ & $4.436 \mathrm{E}-01$ & $6.628 \mathrm{E}-02$ & $5.243 \mathrm{E}-01$ & $0.00 \mathrm{E}+00$ & $1.034 \mathrm{E}+00$ \\
\hline $\mathrm{VOC}$ & $3.971 \mathrm{E}-02$ & $3.726 \mathrm{E}-02$ & $6.262 \mathrm{E}-04$ & $0.00 \mathrm{E}+00$ & $7.759 \mathrm{E}-02$ \\
\hline $\mathbf{C O 2 e} / \mathbf{M W h}$ & $\mathbf{4 . 3 2 E}+\mathbf{0 2}$ & $\mathbf{6 . 8 9 7}+\mathbf{0 1}$ & $\mathbf{2 . 3 6 2 E}+\mathbf{0 3}$ & $\mathbf{3 . 2 6 8 E}+\mathbf{0 0}$ & $\mathbf{2 . 8 6 6 E}+\mathbf{0 3}$ \\
\hline
\end{tabular}

\subsection{Environmental profile for gas power plant}

Table 4. Life cycle greenhouse gas emissions for gas power plant

\begin{tabular}{|l|r|r|r|r|r|}
\cline { 2 - 7 } \multicolumn{1}{c|}{} & \multicolumn{4}{c|}{ Gas Life Cycle Greenhouse Gases Emissions (kg/MWh) } \\
\hline \multicolumn{1}{|c|}{ GHGs } & ERM & \multicolumn{1}{c|}{ TRM } & \multicolumn{1}{c|}{ CRE } & TDE & Total \\
\hline $\mathrm{CH} 4$ & $2.82 \mathrm{E}+00$ & $8.78 \mathrm{E}-01$ & $6.87 \mathrm{E}-02$ & $0.00 \mathrm{E}+00$ & $3.77 \mathrm{E}+00$ \\
\hline $\mathrm{CO}$ & $5.46 \mathrm{E}-02$ & $7.34 \mathrm{E}-02$ & $4.21 \mathrm{E}-02$ & $0.00 \mathrm{E}+00$ & $6.62 \mathrm{E}-02$ \\
\hline $\mathrm{CO} 2$ & $3.08 \mathrm{E}+01$ & $4.86 \mathrm{E}+00$ & $5.97 \mathrm{E}+02$ & $0.00 \mathrm{E}+00$ & $6.33 \mathrm{E}+02$ \\
\hline $\mathrm{Hg}$ & $8.29 \mathrm{E}-02$ & $6.28 \mathrm{E}-03$ & $3.57 \mathrm{E}-03$ & $0.00 \mathrm{E}+00$ & $9.28 \mathrm{E}-02$ \\
\hline $\mathrm{N} 2 \mathrm{O}$ & $7.64 \mathrm{E}-02$ & $5.94 \mathrm{E}-04$ & $2.53 \mathrm{E}-03$ & $0.00 \mathrm{E}+00$ & $7.95 \mathrm{E}-02$ \\
\hline $\mathrm{NH}_{3}$ & $2.11 \mathrm{E}-03$ & $2.19 \mathrm{E}-04$ & $2.95 \mathrm{E}-01$ & $0.00 \mathrm{E}+00$ & $5.28 \mathrm{E}-01$ \\
\hline $\mathrm{NOX}$ & $5.93 \mathrm{E}-04$ & $8.81 \mathrm{E}-03$ & $4.16 \mathrm{E}-02$ & $0.00 \mathrm{E}+00$ & $1.89 \mathrm{E}-01$ \\
\hline $\mathrm{Pb}$ & $2.95 \mathrm{E}-01$ & $2.76 \mathrm{E}-02$ & $3.82 \mathrm{E}-02$ & $0.00 \mathrm{E}+00$ & $3.61 \mathrm{E}-01$ \\
\hline $\mathrm{SF} 6$ & $3.52 \mathrm{E}-02$ & $9.88 \mathrm{E}-04$ & $7.43 \mathrm{E}-04$ & $3.27 \mathrm{E}+00$ & $3.31 \mathrm{E}+00$ \\
\hline $\mathrm{SO} 2$ & $6.98 \mathrm{E}-03$ & $4.26 \mathrm{E}-01$ & $2.28 \mathrm{E}-02$ & $0.00 \mathrm{E}+00$ & $5.19 \mathrm{E}-02$ \\
\hline $\mathrm{VOC}$ & $4.92 \mathrm{E}-03$ & $5.69 \mathrm{E}-03$ & $4.83 \mathrm{E}-01$ & $0.00 \mathrm{E}+00$ & $4.94 \mathrm{E}-01$ \\
\hline $\mathbf{C O 2 e} / \mathbf{M W h}$ & $\mathbf{7 . 9 8 E}+\mathbf{0 1}$ & $\mathbf{4 . 8 7 E}+\mathbf{0 1}$ & $\mathbf{5 . 9 7 E}+\mathbf{0 2}$ & $\mathbf{3 . 2 7 E}+\mathbf{0 0}$ & $\mathbf{7 . 2 8 E}+\mathbf{0 2}$ \\
\hline
\end{tabular}

\subsection{Environmental profile for nuclear power plant}

Table 5. Life cycle greenhouse gas emissions for nuclear power plant

\begin{tabular}{|l|r|r|r|r|r|}
\cline { 2 - 7 } \multicolumn{1}{c|}{} & \multicolumn{4}{c|}{ Nuclear Life Cycle Greenhouse Gases Emissions (kg/MWh) } \\
\hline \multicolumn{1}{c|}{ GHGs } & \multicolumn{1}{c|}{ ERM } & \multicolumn{1}{c|}{ TRM } & \multicolumn{1}{c|}{ CRE } & \multicolumn{1}{c|}{ TDE } & \multicolumn{1}{c|}{ Total } \\
\hline $\mathrm{CH}_{4}$ & $6.18 \mathrm{E}-02$ & $2.89 \mathrm{E}-05$ & $9.98 \mathrm{E}-03$ & $0.00 \mathrm{E}+00$ & $7.181 \mathrm{E}-02$ \\
\hline $\mathrm{CO}$ & $2.62 \mathrm{E}-01$ & $6.77 \mathrm{E}-03$ & $2.37 \mathrm{E}-01$ & $0.00 \mathrm{E}+00$ & $5.057 \mathrm{E}-01$ \\
\hline $\mathrm{CO}_{2}$ & $2.71 \mathrm{E}+01$ & $4.79 \mathrm{E}-02$ & $4.11 \mathrm{E}+00$ & $0.00 \mathrm{E}+00$ & $3.125 \mathrm{E}+01$ \\
\hline $\mathrm{Hg}$ & $2.84 \mathrm{E}-05$ & $5.75 \mathrm{E}-07$ & $2.78 \mathrm{E}-05$ & $0.00 \mathrm{E}+00$ & $5.677 \mathrm{E}-05$ \\
\hline $\mathrm{N}_{2} \mathrm{O}$ & $3.76 \mathrm{E}-04$ & $9.76 \mathrm{E}-06$ & $2.83 \mathrm{E}-05$ & $0.00 \mathrm{E}+00$ & $4.141 \mathrm{E}-04$ \\
\hline $\mathrm{NH}_{3}$ & $9.53 \mathrm{E}-04$ & $4.48 \mathrm{E}-06$ & $2.31 \mathrm{E}-04$ & $0.00 \mathrm{E}+00$ & $1.188 \mathrm{E}-03$ \\
\hline $\mathrm{NOX}$ & $5.41 \mathrm{E}-02$ & $4.51 \mathrm{E}-03$ & $3.16 \mathrm{E}-02$ & $0.00 \mathrm{E}+00$ & $9.021 \mathrm{E}-02$ \\
\hline $\mathrm{Pb}$ & $9.79 \mathrm{E}-05$ & $6.71 \mathrm{E}-06$ & $3.27 \mathrm{E}-04$ & $0.00 \mathrm{E}+00$ & $4.316 \mathrm{E}-04$ \\
\hline $\mathrm{SF}_{6}$ & $2.18 \mathrm{E}-05$ & $5.87 \mathrm{E}-09$ & $5.98 \mathrm{E}-04$ & $3.27 \mathrm{E}+00$ & $3.270 \mathrm{E}+00$ \\
\hline $\mathrm{SO}_{2}$ & $2.58 \mathrm{E}-01$ & $7.63 \mathrm{E}-04$ & $7.83 \mathrm{E}-02$ & $0.00 \mathrm{E}+00$ & $3.371 \mathrm{E}-01$ \\
\hline $\mathrm{VOC}$ & $5.49 \mathrm{E}-03$ & $7.86 \mathrm{E}-04$ & $4.62 \mathrm{E}-02$ & $0.00 \mathrm{E}+00$ & $5.247 \mathrm{E}-02$ \\
\hline $\mathbf{C O 2 e} / \mathbf{M W h}$ & $\mathbf{2 . 7 7 4 E}+01$ & $\mathbf{6 . 0 7 7 E - 0 2}$ & $\mathbf{4 . 5 1 4 E}+\mathbf{0 0}$ & $\mathbf{3 . 2 7 E}+\mathbf{0 0}$ & $\mathbf{3 . 5 5 8 E}+\mathbf{0 1}$ \\
\hline
\end{tabular}




\subsection{Environmental profile for biomass power plant}

Table 6. Life cycle greenhouse gas emissions for biomass power plant

\begin{tabular}{|l|r|r|r|r|r|}
\cline { 2 - 7 } \multicolumn{1}{c|}{} & \multicolumn{3}{c|}{ Biomass Life Cycle Greenhouse Gases Emissions (kg/MWh) } \\
\hline \multicolumn{1}{c|}{ GHGs } & ERM & \multicolumn{1}{c|}{ TRM } & \multicolumn{1}{c|}{ CRE } & \multicolumn{1}{c|}{ TDE } & \multicolumn{1}{c|}{ Total } \\
\hline $\mathrm{CH}_{4}$ & $5.678 \mathrm{E}+00$ & $8.256 \mathrm{E}-02$ & $1.257 \mathrm{E}-01$ & $0.00 \mathrm{E}+00$ & $5.886 \mathrm{E}+00$ \\
\hline $\mathrm{CO}$ & $4.791 \mathrm{E}-01$ & $2.734 \mathrm{E}-02$ & $2.745 \mathrm{E}+01$ & $0.00 \mathrm{E}+00$ & $2.795 \mathrm{E}+01$ \\
\hline $\mathrm{CO}_{2}$ & $9.328 \mathrm{E}+01$ & $7.895 \mathrm{E}+00$ & $1.457 \mathrm{E}+03$ & $0.00 \mathrm{E}+00$ & $1.558 \mathrm{E}+03$ \\
\hline $\mathrm{Hg}$ & $4.854 \mathrm{E}-04$ & $9.381 \mathrm{E}-04$ & $3.546 \mathrm{E}-01$ & $0.00 \mathrm{E}+00$ & $3.560 \mathrm{E}-01$ \\
\hline $\mathrm{N}_{2} \mathrm{O}$ & $4.964 \mathrm{E}-03$ & $3.586 \mathrm{E}-03$ & $2.584 \mathrm{E}-03$ & $0.00 \mathrm{E}+00$ & $1.113 \mathrm{E}-02$ \\
\hline $\mathrm{NH}_{3}$ & $5.485 \mathrm{E}-03$ & $2.762 \mathrm{E}-03$ & $8.397 \mathrm{E}-02$ & $0.00 \mathrm{E}+00$ & $9.223 \mathrm{E}-02$ \\
\hline $\mathrm{NOx}^{\mathrm{Pb}}$ & $3.842 \mathrm{E}-01$ & $2.423 \mathrm{E}-02$ & $9.387 \mathrm{E}-01$ & $0.00 \mathrm{E}+00$ & $1.347 \mathrm{E}+00$ \\
\hline $\mathrm{SF}$ & $3.878 \mathrm{E}-04$ & $2.295 \mathrm{E}-04$ & $2.376 \mathrm{E}-02$ & $0.00 \mathrm{E}+00$ & $2.437 \mathrm{E}-02$ \\
\hline $\mathrm{SOx}$ & $3.969 \mathrm{E}-03$ & $3.789 \mathrm{E}-05$ & $2.829 \mathrm{E}-02$ & $3.268 \mathrm{E}+00$ & $3.300 \mathrm{E}+00$ \\
\hline $\mathrm{VOC}$ & $5.649 \mathrm{E}-01$ & $5.987 \mathrm{E}-02$ & $4.897 \mathrm{E}-01$ & $0.00 \mathrm{E}+00$ & $1.114 \mathrm{E}+00$ \\
\hline $\mathbf{C O 2 e} / \mathbf{M W h}$ & $6.735 \mathrm{E}-02$ & $3.873 \mathrm{E}-03$ & $4.323 \mathrm{E}-01$ & $0.00 \mathrm{E}+00$ & $5.035 \mathrm{E}-01$ \\
\hline
\end{tabular}

\subsection{Environmental profile for wind onshore power plant}

Table 7. Life cycle greenhouse gas emissions for wind onshore power plant

\begin{tabular}{|c|c|c|c|c|c|c|}
\hline \multirow[b]{3}{*}{ GHGs } & \multicolumn{6}{|c|}{ Wind Onshore Life Cycle Greenhouse Gases Emissions (kg/MWh) } \\
\hline & \multicolumn{5}{|c|}{ CRE facility } & \\
\hline & TRKC & TBNM & WFC & WFO & LFW & \\
\hline $\mathrm{CH}_{4}$ & 9.448E-03 & $8.97 \mathrm{E}-02$ & $5.43 \mathrm{E}-03$ & $3.23 \mathrm{E}-02$ & $3.11 \mathrm{E}-04$ & $0.00 \mathrm{E}+00$ \\
\hline $\mathrm{CO}$ & $8.72 \mathrm{E}-02$ & $3.12 \mathrm{E}-01$ & $9.64 \mathrm{E}-02$ & $2.47 \mathrm{E}-03$ & $8.29 \mathrm{E}-05$ & $0.00 \mathrm{E}+00$ \\
\hline $\mathrm{CO}_{2}$ & 9.39E-01 & $4.47 \mathrm{E}+00$ & $2.15 \mathrm{E}-01$ & $1.44 \mathrm{E}-01$ & $1.06 \mathrm{E}-02$ & $0.00 \mathrm{E}+00$ \\
\hline $\mathrm{Hg}$ & $7.23 \mathrm{E}-06$ & $8.96 \mathrm{E}-07$ & $4.45 \mathrm{E}-09$ & $2.45 \mathrm{E}-10$ & $4.97 \mathrm{E}-11$ & $0.00 \mathrm{E}+00$ \\
\hline $\mathrm{N}_{2} \mathrm{O}$ & $3.32 \mathrm{E}-04$ & $9.36 \mathrm{E}-03$ & $5.68 \mathrm{E}-04$ & $6.41 \mathrm{E}-04$ & $8.74 \mathrm{E}-08$ & $0.00 \mathrm{E}+00$ \\
\hline $\mathrm{NH}_{3}$ & $4.35 \mathrm{E}-04$ & $2.37 \mathrm{E}-04$ & $4.46 \mathrm{E}-04$ & $2.23 \mathrm{E}-05$ & $3.32 \mathrm{E}-07$ & $0.00 \mathrm{E}+00$ \\
\hline $\mathrm{NOX}$ & $2.71 \mathrm{E}-02$ & $9.82 \mathrm{E}-02$ & $4.26 \mathrm{E}-03$ & $3.26 \mathrm{E}-03$ & $9.46 \mathrm{E}-05$ & $0.00 \mathrm{E}+00$ \\
\hline $\mathrm{Pb}$ & $2.17 \mathrm{E}-04$ & $5.68 \mathrm{E}-04$ & $4.82 \mathrm{E}-05$ & $7.34 \mathrm{E}-07$ & $4.96 \mathrm{E}-10$ & $0.00 \mathrm{E}+00$ \\
\hline $\mathrm{SF}_{6}$ & $1.53 \mathrm{E}-05$ & $6.96 \mathrm{E}-04$ & $8.203 \mathrm{E}-06$ & $8.35 \mathrm{E}-07$ & $2.63 \mathrm{E}-15$ & $3.27 \mathrm{E}+00$ \\
\hline $\mathrm{SO}_{2}$ & $3.58 \mathrm{E}-02$ & $2.61 \mathrm{E}-01$ & $3.21 \mathrm{E}-03$ & $8.45 \mathrm{E}-04$ & $4.79 \mathrm{E}-05$ & $0.00 \mathrm{E}+00$ \\
\hline VOC & $2.68 \mathrm{E}-03$ & $3.86 \mathrm{E}-02$ & $6.52 \mathrm{E}-03$ & $2.34 \mathrm{E}-04$ & $2.87 \mathrm{E}-05$ & $0.00 \mathrm{E}+00$ \\
\hline CO2e/MWh & $1.102 \mathrm{E}+00$ & $5.287 \mathrm{E}+00$ & 3.326E-01 & 1.83E-01 & 1.12E-02 & $3.27 \mathrm{E}+00$ \\
\hline
\end{tabular}

\subsection{Environmental profile for wind offshore power plant}

Table 8. Life cycle greenhouse gas emissions for wind offshore power plant

\begin{tabular}{|c|c|c|c|c|c|c|}
\hline & \multicolumn{6}{|c|}{ Wind Offshore Life Cycle Greenhouse Gases Emissions (kg/MWh) } \\
\hline & \multicolumn{5}{|c|}{ CRE facility } & \\
\hline & TRKC & TBNM & WFC & WFO & LFW & \\
\hline $\mathrm{CH}_{4}$ & $1.346 \mathrm{E}-02$ & $8.862 \mathrm{E}-03$ & $3.795 \mathrm{E}-03$ & $2.367 \mathrm{E}-02$ & $3.12 \mathrm{E}-04$ & \\
\hline $\mathrm{CO}$ & $8.72 \mathrm{E}-02$ & $2.45 \mathrm{E}-01$ & $4.57 \mathrm{E}-02$ & 5.84E-02 & $6.54 \mathrm{E}-04$ & $0.00 \mathrm{E}+00$ \\
\hline $\mathrm{CO}_{2}$ & 9.393E-01 & $3.872 \mathrm{E}+00$ & $4.141 \mathrm{E}+00$ & $1.310 \mathrm{E}+01$ & $1.06 \mathrm{E}-02$ & $0.00 \mathrm{E}+00$ \\
\hline $\mathrm{Hg}$ & 7.24E-09 & $6.48 \mathrm{E}-06$ & $6.17 \mathrm{E}-07$ & $4.65 \mathrm{E}-07$ & $3.83 \mathrm{E}-11$ & $0.00 \mathrm{E}+00$ \\
\hline $\mathrm{N}_{2} \mathrm{O}$ & $1.091 \mathrm{E}-04$ & $8.615 \mathrm{E}-03$ & $2.036 \mathrm{E}-04$ & $4.561 \mathrm{E}-04$ & $8.77 \mathrm{E}-08$ & $0.00 \mathrm{E}+00$ \\
\hline $\mathrm{NH}_{3}$ & $4.36 \mathrm{E}-06$ & $9.65 \mathrm{E}-04$ & $5.72 \mathrm{E}-05$ & $2.81 \mathrm{E}-03$ & $2.76 \mathrm{E}-06$ & $0.00 \mathrm{E}+00$ \\
\hline NOX & $2.72 \mathrm{E}-03$ & $7.74 \mathrm{E}-02$ & $7.86 \mathrm{E}-03$ & $2.62 \mathrm{E}-01$ & 7.42E-03 & $0.00 \mathrm{E}+00$ \\
\hline $\mathrm{Pb}$ & $2.17 \mathrm{E}-06$ & $4.25 \mathrm{E}-06$ & $8.27 \mathrm{E}-05$ & $6.59 \mathrm{E}-06$ & $3.82 \mathrm{E}-10$ & $0.00 \mathrm{E}+00$ \\
\hline $\mathrm{SF}_{6}$ & 3.779E-06 & $3.137 \mathrm{E}-05$ & $4.790 \mathrm{E}-07$ & $1.376 \mathrm{E}-06$ & $2.64 \mathrm{E}-15$ & $3.27 \mathrm{E}+00$ \\
\hline $\mathrm{SO}_{2}$ & $3.58 \mathrm{E}-03$ & $2.17 \mathrm{E}-02$ & $8.62 \mathrm{E}-03$ & $2.59 \mathrm{E}-02$ & $3.89 \mathrm{E}-04$ & $0.00 \mathrm{E}+00$ \\
\hline VOC & $2.68 \mathrm{E}-04$ & $3.12 \mathrm{E}-03$ & $2.84 \mathrm{E}-04$ & $7.31 \mathrm{E}-03$ & $2.59 \mathrm{E}-04$ & $0.00 \mathrm{E}+00$ \\
\hline CO2e/MWh & $1.046 \mathrm{E}+00$ & $4.237 \mathrm{E}+00$ & $4.207 \mathrm{E}+00$ & $1.348 \mathrm{E}+01$ & 1.963E-02 & $3.27 \mathrm{E}+00$ \\
\hline
\end{tabular}




\subsection{Environmental profile for Geothermal power plant}

Table 9. Life cycle greenhouse gas emissions for geothermal power plant

\begin{tabular}{|c|c|c|c|c|c|c|}
\hline \multirow[b]{3}{*}{ 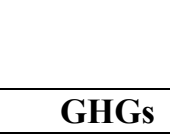 } & \multicolumn{6}{|c|}{ Geothermal Life Cycle Greenhouse Gases Emissions (kg/MWh) } \\
\hline & \multicolumn{5}{|c|}{ CRE facility } & \\
\hline & PPLC & PMFCT & PLTC & TRKC & WLC & \\
\hline $\mathrm{CH}_{4}$ & $8.35 \mathrm{E}-03$ & $6.393 \mathrm{E}-04$ & $5.95 \mathrm{E}-04$ & $8.84 \mathrm{E}-03$ & $1.167 \mathrm{E}-04$ & $0.00 \mathrm{E}+00$ \\
\hline $\mathrm{CO}$ & 7.33E-02 & $2.87 \mathrm{E}-01$ & $3.87 \mathrm{E}-02$ & 5.74E-03 & $2.61 \mathrm{E}-02$ & $0.00 \mathrm{E}+00$ \\
\hline $\mathrm{CO}_{2}$ & $9.96 \mathrm{E}-02$ & 4.634E-01 & $5.38 \mathrm{E}-01$ & $6.71 \mathrm{E}-01$ & 4.199E-01 & $0.00 \mathrm{E}+00$ \\
\hline $\mathrm{Hg}$ & 7.64E-05 & $3.43 \mathrm{E}-04$ & $3.74 \mathrm{E}-06$ & 4.67E-05 & $6.23 \mathrm{E}-06$ & $0.00 \mathrm{E}+00$ \\
\hline $\mathrm{N}_{2} \mathrm{O}$ & $5.78 \mathrm{E}-06$ & $3.150 \mathrm{E}-06$ & $2.17 \mathrm{E}-04$ & $8.67 \mathrm{E}-06$ & 4.794E-06 & $0.00 \mathrm{E}+00$ \\
\hline $\mathrm{NH}_{3}$ & $3.37 \mathrm{E}-03$ & $2.23 \mathrm{E}-04$ & $3.76 \mathrm{E}-03$ & $2.83 \mathrm{E}-04$ & $8.25 \mathrm{E}-05$ & $0.00 \mathrm{E}+00$ \\
\hline $\mathrm{NOX}$ & $3.11 \mathrm{E}-02$ & $6.97 \mathrm{E}-03$ & $8.25 \mathrm{E}-02$ & $8.63 \mathrm{E}-03$ & $5.77 \mathrm{E}-02$ & $0.00 \mathrm{E}+00$ \\
\hline $\mathrm{Pb}$ & $3.58 \mathrm{E}-04$ & $5.48 \mathrm{E}-03$ & $3.84 \mathrm{E}-04$ & $5.81 \mathrm{E}-07$ & $2.98 \mathrm{E}-04$ & $0.00 \mathrm{E}+00$ \\
\hline $\mathrm{SF}_{6}$ & $2.85 \mathrm{E}-07$ & $1.167 \mathrm{E}-06$ & $2.47 \mathrm{E}-08$ & $9.35 \mathrm{E}-06$ & $3.216 \mathrm{E}-08$ & $1.43 \mathrm{E}-04$ \\
\hline $\mathrm{SO}_{2}$ & $3.45 \mathrm{E}-02$ & $9.59 \mathrm{E}-03$ & $3.62 \mathrm{E}-02$ & $2.56 \mathrm{E}-02$ & $3.34 \mathrm{E}-03$ & $0.00 \mathrm{E}+00$ \\
\hline VOC & $3.82 \mathrm{E}-04$ & $2.89 \mathrm{E}-04$ & $3.14 \mathrm{E}-03$ & $8.14 \mathrm{E}-04$ & $2.35 \mathrm{E}-03$ & $0.00 \mathrm{E}+00$ \\
\hline CO2e/MWh & 2.510E-01 & 7.739E-01 & $7.088 \mathrm{E}-01$ & $\begin{array}{r}7.209 \mathrm{E}- \\
01\end{array}$ & $\begin{array}{r}5.098 E- \\
01\end{array}$ & $3.27 \mathrm{E}+00$ \\
\hline
\end{tabular}

4.8 Environmental profile for solar thermal power plant

Table 10. Life cycle greenhouse gas emissions for solar thermal power plant

\begin{tabular}{|c|c|c|c|c|c|c|}
\hline \multirow[b]{3}{*}{$\mathbf{G}$} & \multicolumn{6}{|c|}{ Solar Thermal Life Cycle Greenhouse Gases Emissions (kg/MWh) } \\
\hline & \multicolumn{4}{|c|}{ CRE facility } & \multirow[t]{2}{*}{ TDE } & \multirow[t]{2}{*}{ Total } \\
\hline & PLTC & CLTC & STO & TRKC & & \\
\hline $\mathrm{CH}_{4}$ & 4.12E-03 & $6.13 \mathrm{E}-02$ & $5.78 \mathrm{E}-02$ & 5.23E-04 & $0.00 \mathrm{E}+00$ & $1.237 \mathrm{E}-01$ \\
\hline $\mathrm{CO}$ & 5.99E-02 & $7.86 \mathrm{E}-02$ & $5.98 \mathrm{E}-01$ & $3.65 \mathrm{E}-03$ & $0.00 \mathrm{E}+00$ & $7.401 \mathrm{E}-01$ \\
\hline $\mathrm{CO}_{2}$ & $2.73 \mathrm{E}+00$ & $1.110 \mathrm{E}+01$ & $2.80 \mathrm{E}+01$ & 4.07E-01 & $0.00 \mathrm{E}+00$ & $4.226 \mathrm{E}+01$ \\
\hline $\mathrm{Hg}$ & $2.76 \mathrm{E}-08$ & $8.83 \mathrm{E}-06$ & $3.86 \mathrm{E}-09$ & $2.87 \mathrm{E}-09$ & $0.00 \mathrm{E}+00$ & $9.521 \mathrm{E}-06$ \\
\hline $\mathrm{N}_{2} \mathrm{O}$ & $2.15 \mathrm{E}-05$ & $6.987 \mathrm{E}-03$ & 8.07E-04 & $5.25 \mathrm{E}-06$ & $0.00 \mathrm{E}+00$ & $7.821 \mathrm{E}-03$ \\
\hline $\mathrm{NH}_{3}$ & $5.21 \mathrm{E}-05$ & $2.97 \mathrm{E}-05$ & $6.88 \mathrm{E}-06$ & $2.15 \mathrm{E}-06$ & $0.00 \mathrm{E}+00$ & $9.083 \mathrm{E}-05$ \\
\hline NOX & $2.83 \mathrm{E}-02$ & 4.64E-02 & $5.24 \mathrm{E}-02$ & $6.32 \mathrm{E}-04$ & $0.00 \mathrm{E}+00$ & $1.277 \mathrm{E}-01$ \\
\hline $\mathrm{Pb}$ & $2.77 \mathrm{E}-06$ & $2.67 \mathrm{E}-05$ & 5.85E-08 & $3.68 \mathrm{E}-07$ & $0.00 \mathrm{E}+00$ & $3.042 \mathrm{E}-05$ \\
\hline $\mathrm{SF}_{6}$ & $1.27 \mathrm{E}-05$ & $6.221 \mathrm{E}-06$ & $1.22 \mathrm{E}-06$ & $5.37 \mathrm{E}-09$ & $3.27 \mathrm{E}+00$ & $3.268 \mathrm{E}+00$ \\
\hline $\mathrm{SO}_{2}$ & $4.26 \mathrm{E}-03$ & $6.39 \mathrm{E}-02$ & $3.48 \mathrm{E}-03$ & $9.12 \mathrm{E}-04$ & $0.00 \mathrm{E}+00$ & $7.255 \mathrm{E}-02$ \\
\hline VOC & $7.61 \mathrm{E}-04$ & $3.86 \mathrm{E}-02$ & $8.51 \mathrm{E}-03$ & $5.85 \mathrm{E}-05$ & $0.00 \mathrm{E}+00$ & 4.792E-02 \\
\hline CO2e/MWh & $2.83 E+00$ & $1.139 \mathrm{E}+01$ & $2.87 \mathrm{E}+01$ & 4.13E-01 & $3.27 \mathrm{E}+00$ & $4.665 \mathrm{E}+01$ \\
\hline
\end{tabular}

\subsection{Environmental profile for hydro power plant}

Table 11. Life cycle greenhouse gas emissions for hydro power plant

\begin{tabular}{|l|r|r|c|c|c|}
\cline { 2 - 7 } \multicolumn{1}{c|}{} & \multicolumn{5}{c|}{ Hydro Life Cycle Greenhouse Gases Emissions (kg/MWh) } \\
\cline { 2 - 7 } \multicolumn{1}{c|}{ GHGs } & \multicolumn{1}{c|}{ TRKC } & \multicolumn{1}{c|}{ DHFC } & HPO & TDE & Total \\
\hline $\mathrm{CH}_{4}$ & $1.337 \mathrm{E}-04$ & $8.306 \mathrm{E}-03$ & $3.62 \mathrm{E}-01$ & $0.00 \mathrm{E}+00$ & $3.703 \mathrm{E}-01$ \\
\hline $\mathrm{CO}$ & $4.49 \mathrm{E}-02$ & $2.28 \mathrm{E}-01$ & $0.00 \mathrm{E}+00$ & $0.00 \mathrm{E}+00$ & $2.729 \mathrm{E}-01$ \\
\hline $\mathrm{CO}_{2}$ & $6.426 \mathrm{E}-02$ & $9.97 \mathrm{E}+00$ & $2.92 \mathrm{E}+01$ & $0.00 \mathrm{E}+00$ & $3.924 \mathrm{E}+01$ \\
\hline $\mathrm{Hg}$ & $3.73 \mathrm{E}-07$ & $6.35 \mathrm{E}-04$ & $0.00 \mathrm{E}+00$ & $0.00 \mathrm{E}+00$ & $6.387 \mathrm{E}-04$ \\
\hline $\mathrm{N}_{2} \mathrm{O}$ & $1.286 \mathrm{E}-05$ & $6.036 \mathrm{E}-05$ & $0.00 \mathrm{E}+00$ & $0.00 \mathrm{E}+00$ & $7.322 \mathrm{E}-04$ \\
\hline $\mathrm{NH}_{3}$ & $2.51 \mathrm{E}-04$ & $3.52 \mathrm{E}-03$ & $0.00 \mathrm{E}+00$ & $0.00 \mathrm{E}+00$ & $3.771 \mathrm{E}-03$ \\
\hline $\mathrm{NOX}$ & $7.86 \mathrm{E}-03$ & $2.83 \mathrm{E}-02$ & $0.00 \mathrm{E}+00$ & $0.00 \mathrm{E}+00$ & $3.616 \mathrm{E}-02$ \\
\hline $\mathrm{Pb}$ & $4.53 \mathrm{E}-05$ & $5.58 \mathrm{E}-06$ & $0.00 \mathrm{E}+00$ & $0.00 \mathrm{E}+00$ & $5.088 \mathrm{E}-05$ \\
\hline
\end{tabular}




\begin{tabular}{|l|r|r|r|r|r|}
\hline $\mathrm{SF}_{6}$ & $1.355 \mathrm{E}-06$ & $5.652 \mathrm{E}-06$ & $0.00 \mathrm{E}+00$ & $2.54 \mathrm{E}-04$ & $2.610 \mathrm{E}-04$ \\
\hline $\mathrm{SO}_{2}$ & $2.18 \mathrm{E}-03$ & $2.34 \mathrm{E}-02$ & $0.00 \mathrm{E}+00$ & $0.00 \mathrm{E}+00$ & $2.558 \mathrm{E}-02$ \\
\hline VOC & $7.71 \mathrm{E}-07$ & $6.82 \mathrm{E}-03$ & $0.00 \mathrm{E}+00$ & $0.00 \mathrm{E}+00$ & $6.827 \mathrm{E}-03$ \\
\hline $\mathbf{C O 2 e} / \mathbf{M W h}$ & $\mathbf{1 . 1 9 E}-\mathbf{0 1}$ & $\mathbf{1 . 0 3 E}+\mathbf{0 1}$ & $\mathbf{2 . 9 6 E}+\mathbf{0 1}$ & $\mathbf{2 . 5 4 E - 0 4}$ & $\mathbf{3 . 9 9 E}+\mathbf{0 1}$ \\
\hline
\end{tabular}

\section{Data analysis}

This section aims at analyzing the results of the greenhouse gas grid emission factor for each electricity generating technology as presented in the previous section. The analysis is based on the entire life cycle.

\subsection{Environmental assessment for coal power plant}

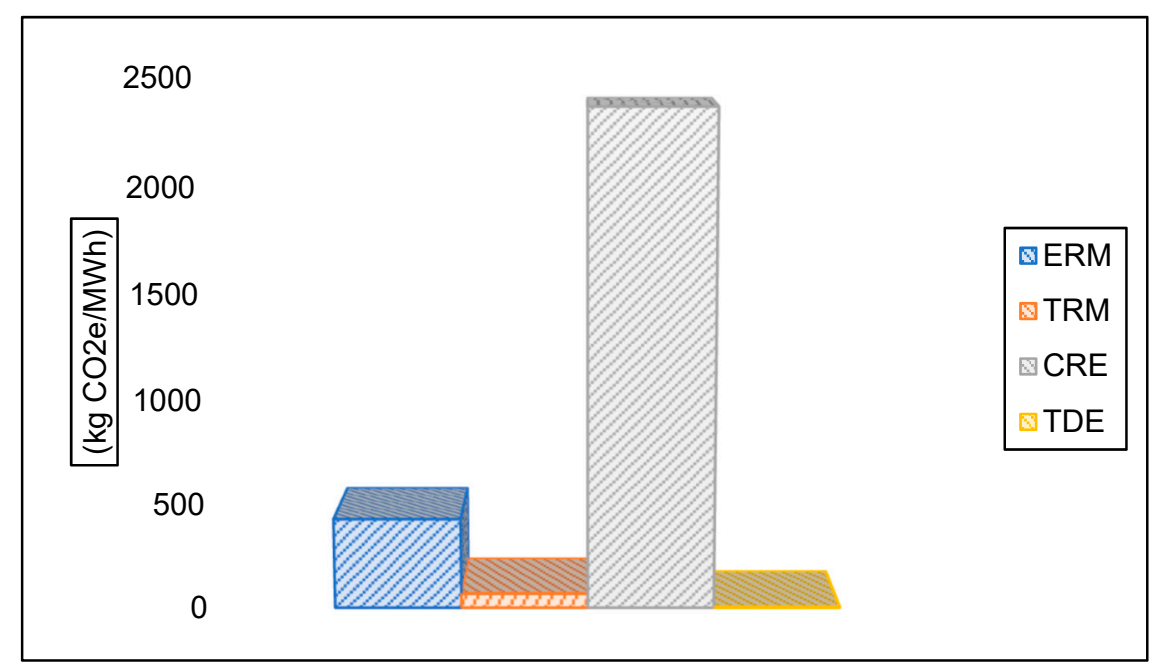

Figure 1. life cycle greenhouse gas for coal power plant

From the figure above, it can be depicted that the life cycle greenhouse gas grid emission factor of coal electricity generating source varies widely depending upon life cycle stage. For instance, at ERM the GEF is around $432 \mathrm{~kg} \mathrm{CO} 2 \mathrm{e} / \mathrm{MWh}$ this is due to various activities involved during the extraction process of raw material. This amount goes down to $68.97 \mathrm{CO} 2 \mathrm{e} / \mathrm{MWh}$ at TRM this is due to the transport system and the distance from the mining to the plant. Generally, coal is always moved by railway or truck. Direct ecological effects can take place at the mine, where the coal is being moved, conveyed or loaded. indirect ecological bearings from coal transportation mainly result from the combustion of fuel for the transportation itself. No surprisingly, the figure of GEF increases at $2362 \mathrm{~kg} \mathrm{CO} 2 \mathrm{e} / \mathrm{MWh}$ at CRE. Whilst, at TDE stage the GEF decreases to 3.268. it should be noted that at TDE stage only the Sulphur hexafluoride is realised into the air. The reason may be due to the fact it is seen as an excellent electrical insulator for high voltage. 


\subsection{Environmental assessment for gas power plant}

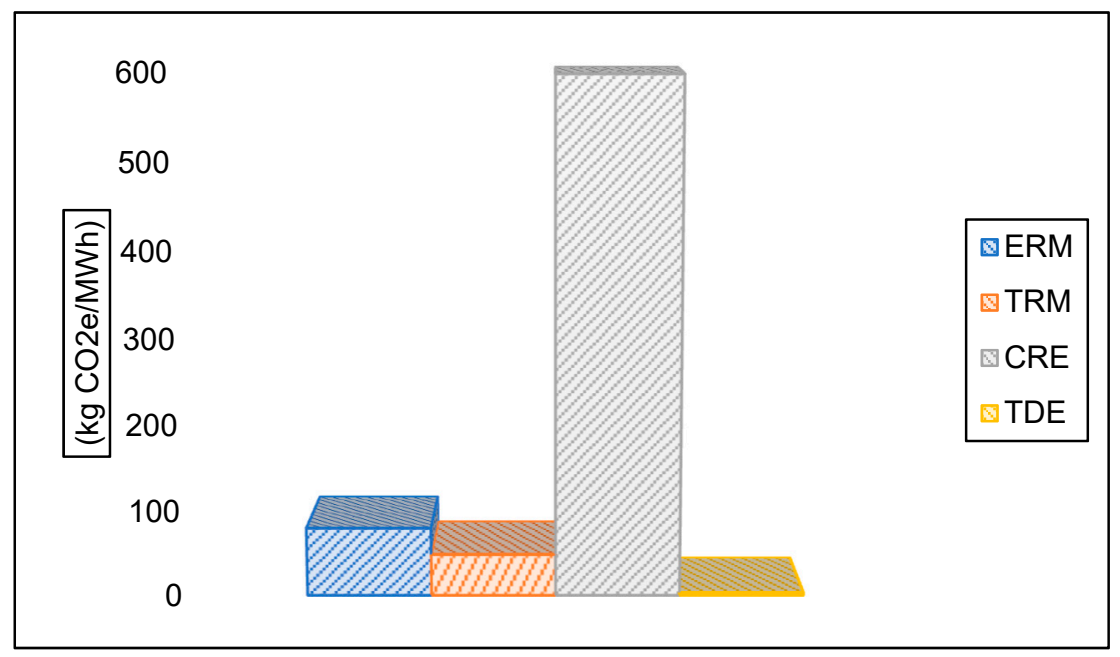

Figure 2. life cycle greenhouse gas for gas power plant

The figure 2 above shows that the GEF related to ERM and TRM of gas power range from 79.8 $\mathrm{kg} \mathrm{CO} 2 \mathrm{e} / \mathrm{MWh}$ to $48.7 \mathrm{~kg} \mathrm{CO} 2 \mathrm{e} / \mathrm{MWh}$. The results for ERM is mostly influenced by various fluids for hydraulic fracturing that are often employed to extract the gas, and most of those fluids contain various chemical compounds. Whilst, the GEF results for TRM depend largely upon the distance and pipeline leakage. At the CRE stage, the figure increases to $597 \mathrm{~kg} \mathrm{CO} 2 \mathrm{e} / \mathrm{MWh}$, and TDE it goes down to $3.27 \mathrm{~kg} \mathrm{CO} 2 \mathrm{e} / \mathrm{MWh}$. As with coal energy generating source at TDE stage when conveying the electricity from gas to the end-users the Sulphur hexafluoride is realised into the air. The reason may be due to the fact it is seen as an excellent electrical insulator for high voltage.

\subsection{Environmental assessment for nuclear power plant}

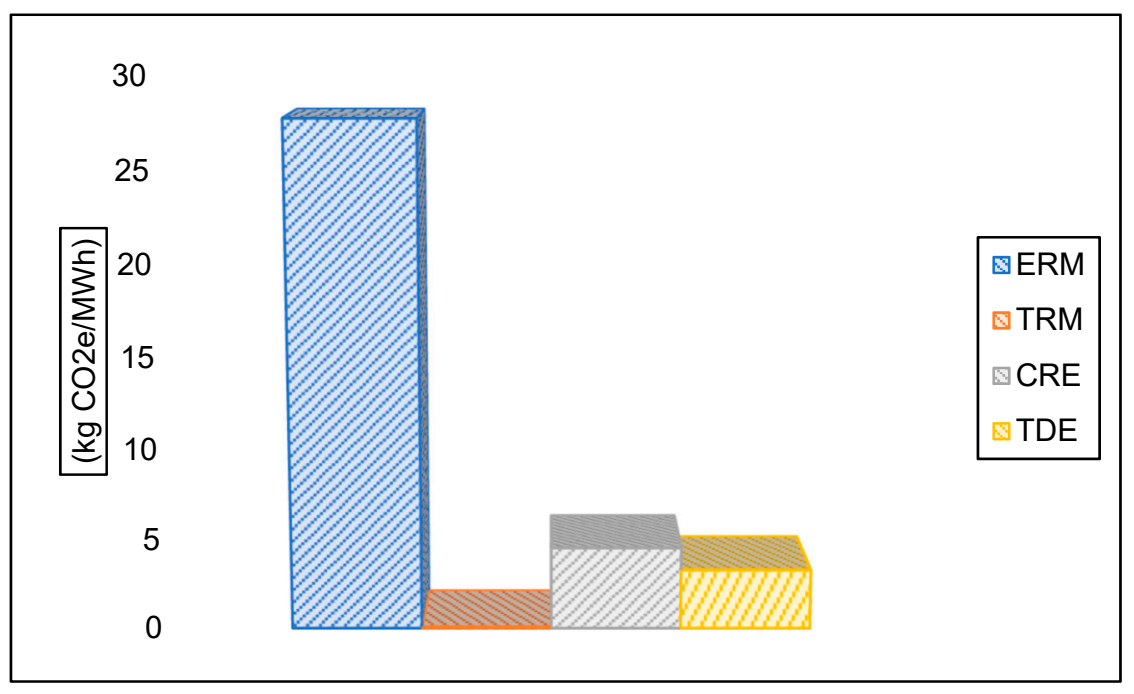

Figure 3. life cycle greenhouse gas for nuclear power plant

Various studies have argued that nuclear energy generating source is the best answer to climate change issue since it does not release greenhouse gas emission into the air. Whilst this argument maybe true, it is also misleading when considering the amount of GHGs that maybe produced by nuclear power plant. Because, during the operation of nuclear power plants there is always an 
insignificant GHGs emissions that are realised into the air. For example, in the case of our study we can see nearly $4.51 \mathrm{~kg} \mathrm{CO} 2 \mathrm{e} / \mathrm{MWh}$ are generated during the operation of nuclear power plant. Additionally, the figure 3 above, shows that at ERM stage a significant amount of GHGs are discharged into the environment, these emissions are linked to the activities associated with enrichment of uranium. The TRM of radioactive waste also yields carbon dioxide emissions in our study is estimated at $0.06 \mathrm{~kg} \mathrm{CO} 2 \mathrm{e} / \mathrm{MWh}$. As with coal energy generating source at TDE stage when conveying the electricity from nuclear to the end-users the amount of Sulphur hexafluoride realised into the air is estimated at $3.27 \mathrm{~kg} \mathrm{CO} 2 \mathrm{e} / \mathrm{MWh}$. The reason may be due to the fact it is seen as an excellent electrical insulator for high voltage.

\subsection{Environmental assessment for biomass power plant}

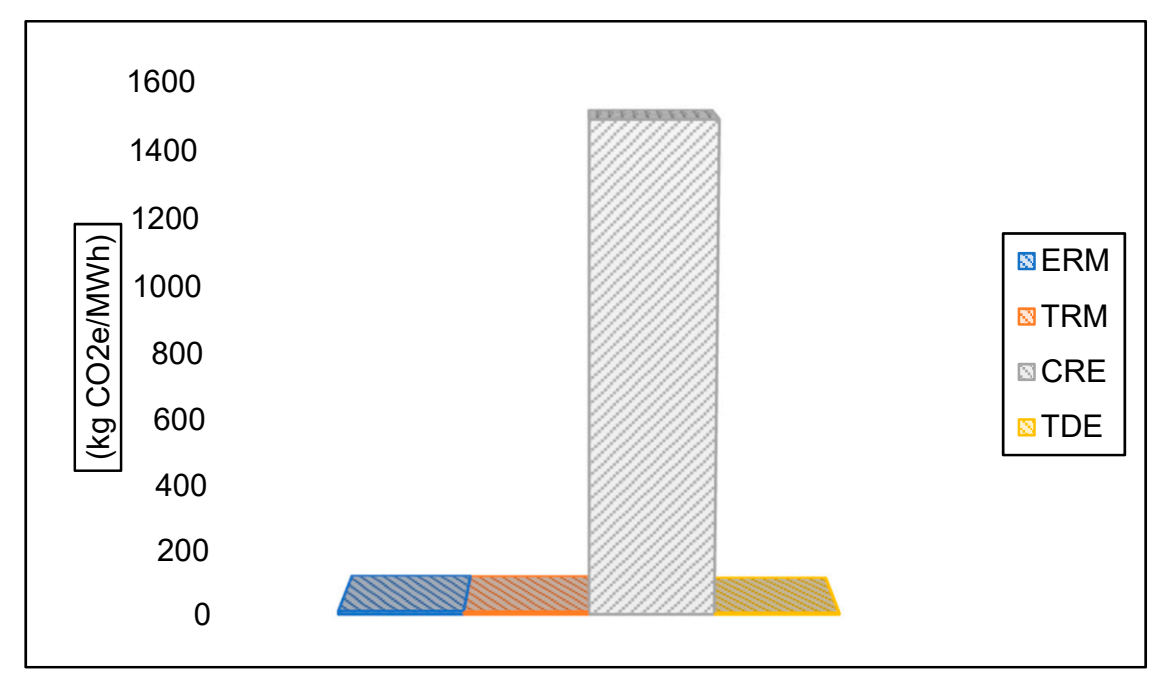

Figure 4. life cycle greenhouse gas for biomass power plant

From the figure above, it can be depicted that the life cycle greenhouse gas grid emission factor of biomass electricity generating source varies widely depending upon life cycle stage. For instance, at ERM the GEF is around $10.05 \mathrm{~kg} \mathrm{CO} 2 \mathrm{e} / \mathrm{MWh}$ this is due to various activities involved during the extraction process of raw material. The GHGs at TRM phases amounted to $8.1 \mathrm{~kg} \mathrm{CO} 2 \mathrm{e} / \mathrm{MWh}$. Whilst, the figure of GHGs at CRE increases to $1487 \mathrm{~kg} \mathrm{CO} 2 \mathrm{e} / \mathrm{MWh}$. Lastly, as with other power generating sources presented in the above sections. At TDE stage when conveying the electricity from biomass to the end-users the amount of Sulphur hexafluoride realised into the air is estimated at $3.268 \mathrm{~kg} \mathrm{CO} 2 \mathrm{e} / \mathrm{MWh}$. The reason may be due to the fact it is seen as an excellent electrical insulator for high voltage. 


\subsection{Environmental assessment for wind onshore power plant}

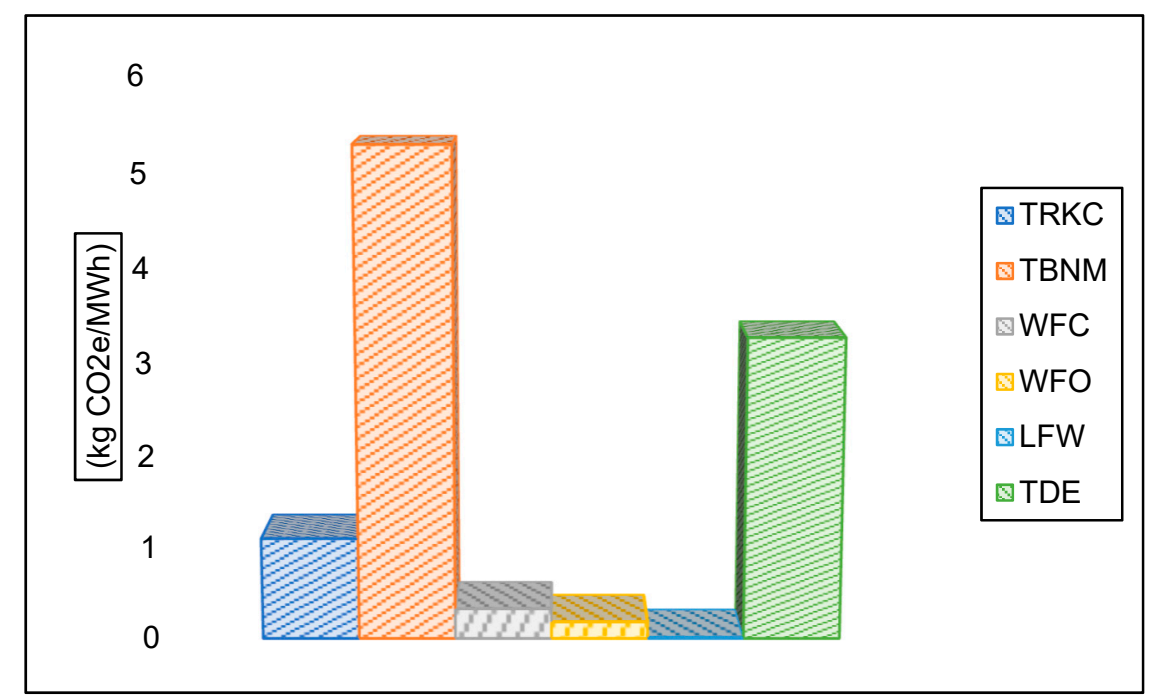

Figure 5. life cycle greenhouse gas for wind onshore power plant

Unlike with conventional energy sources, the emissions linked to the wind onshore power plant are associated with the activities of manufacturing and constructing of CRE facilities. Since wind does not require extraction and transportation. Thus, considering the impact that wind onshore facilities may have on the environment the figure above shows the life cycle GHGs related to Trunkline Construction (TRKC) amounted to $1.102 \mathrm{~kg} \mathrm{CO} 2 \mathrm{e} / \mathrm{MWh}$, Turbine Manufacturing (TBNM) estimated at $5.287 \mathrm{~kg} \mathrm{CO} 2 \mathrm{e} / \mathrm{MWh}$, wind farm operation (WFO) evaluated at $0.183 \mathrm{~kg}$ $\mathrm{CO} 2 \mathrm{e} / \mathrm{MWh}$, Wind Farm Construction (WFC) amounted to $0.33 \mathrm{~kg} \mathrm{CO} 2 \mathrm{e} / \mathrm{MWh}$, Landfille Waste (LFW) estimated at $0.011 \mathrm{~kg} \mathrm{CO} e / \mathrm{MWh}$. Lastly, as with other power generating sources presented in the above sections. At TDE stage when conveying the electricity from wind onshore to the end-users the amount of Sulphur hexafluoride realised into the air is estimated at $3.27 \mathrm{~kg}$ $\mathrm{CO} 2 \mathrm{e} / \mathrm{MWh}$. The reason may be due to the fact it is seen as an excellent electrical insulator for high voltage.

\subsection{Environmental assessment for wind offshore power plant}

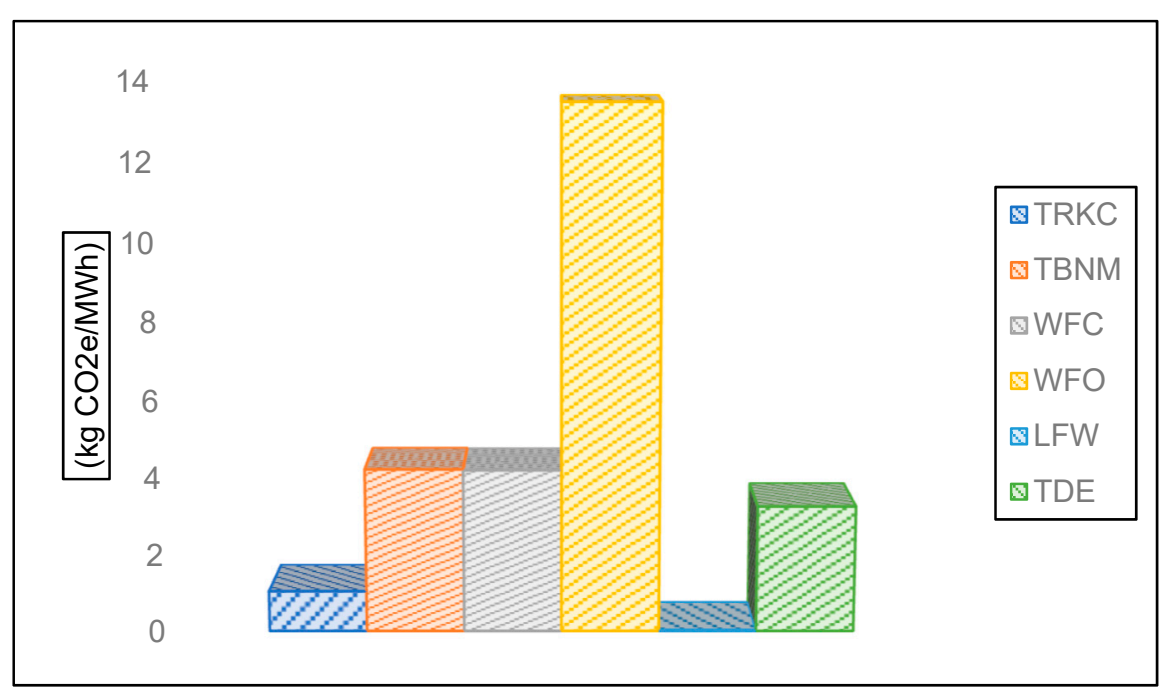

Figure 6. life cycle greenhouse gas for wind offshore power plant

As with wind onshore energy sources, the emissions linked to the wind offshore power plant are associated with the activities of manufacturing and constructing of CRE facilities. Since wind 
does not require extraction and transportation. Thus, considering the impact that wind onshore facilities may have on the environment the figure above shows the life cycle GHGs related to Trunkline Construction (TRKC) amounted to $1.046 \mathrm{~kg} \mathrm{CO} \mathrm{e} / \mathrm{MWh}$, Turbine Manufacturing (TBNM) estimated at $4.23 \mathrm{~kg} \mathrm{CO} 2 \mathrm{e} / \mathrm{MWh}$, wind farm operation (WFO) evaluated at $13.48 \mathrm{~kg}$ CO2e/MWh, Wind Farm Construction (WFC) amounted to $4.21 \mathrm{~kg} \mathrm{CO} e / \mathrm{MWh}$, Landfille Waste (LFW) estimated at $0.019 \mathrm{~kg} \mathrm{CO2e} / \mathrm{MWh}$. Lastly, as with other power generating sources presented in the above sections. At TDE stage when conveying the electricity from wind offshore to the end-users the amount of Sulphur hexafluoride realised into the air is estimated at $3.27 \mathrm{~kg}$ $\mathrm{CO} 2 \mathrm{e} / \mathrm{MWh}$. The reason may be due to the fact it is seen as an excellent electrical insulator for high voltag

\subsection{Environmental assessment for geothermal power plant}

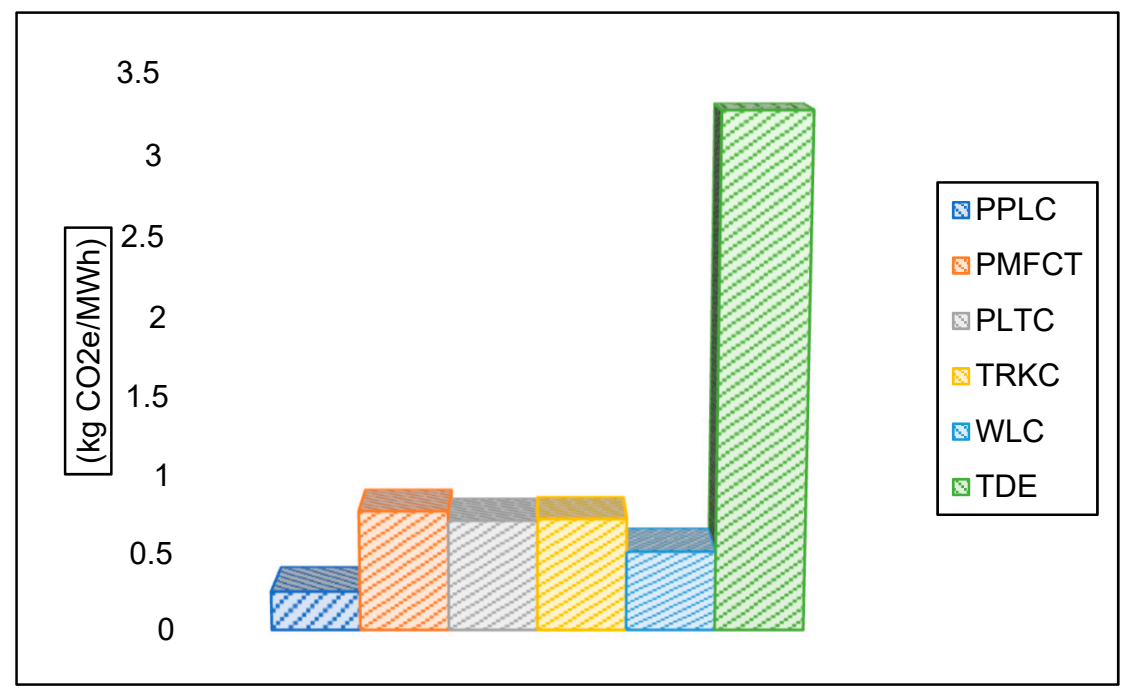

Figure 7. life cycle greenhouse gas for geothermal power plant

Geothermal energy is thermal energy produced and stored in the Earth. Thermal energy is the energy that regulates the heat of substance. The geothermal energy of the Earth's crust derives from the creation of the earth (20\%) and from radioactive decomposition of natural resources $(80 \%)$. The geothermal gradient that is the difference within heat involving the heart of the earth and its surface, creates an incessant transmission of electrical energy within the form of temperature from the heart to the surface. Earth's core temperature is thermal energy produced throughout the degeneration of radioactive and constant temperature loss from planet's formation. Hence, it does not require extraction and transportation. Thus, this study presents the life cycle GHGs emissions associated with the manufacturing and construction of geothermal CRE facilities. As it can be seen from the figure 7 above shows that the life cycle GHGs related to Pipeline construction (PPLC) amounted to $0.25 \mathrm{~kg} \mathrm{CO} 2 \mathrm{e} / \mathrm{MWh}$, Plant construction (PLTC) estimated at $0.71 \mathrm{~kg} \mathrm{CO} 2 \mathrm{e} / \mathrm{MWh}, \mathrm{PMFCT}$ evaluated at $0.77 \mathrm{~kg} \mathrm{CO} 2 \mathrm{e} / \mathrm{MWh}$, Trunkline Construction (TRKC) amounted to $0.72 \mathrm{~kg} \mathrm{CO} 2 \mathrm{e} / \mathrm{MWh}$, well construction (WLC) estimated at $0.051 \mathrm{~kg} \mathrm{CO} 2 \mathrm{e} / \mathrm{MWh}$. Lastly, as with other power generating sources presented in the above sections. At TDE stage when conveying the electricity from geothermal to the end-users the amount of Sulphur hexafluoride realised into the air is estimated at $3.27 \mathrm{~kg} \mathrm{CO} 2 \mathrm{e} / \mathrm{MWh}$. The reason may be due to the fact it is seen as an excellent electrical insulator for high voltage. 


\subsection{Environmental assessment for solar thermal power plant}

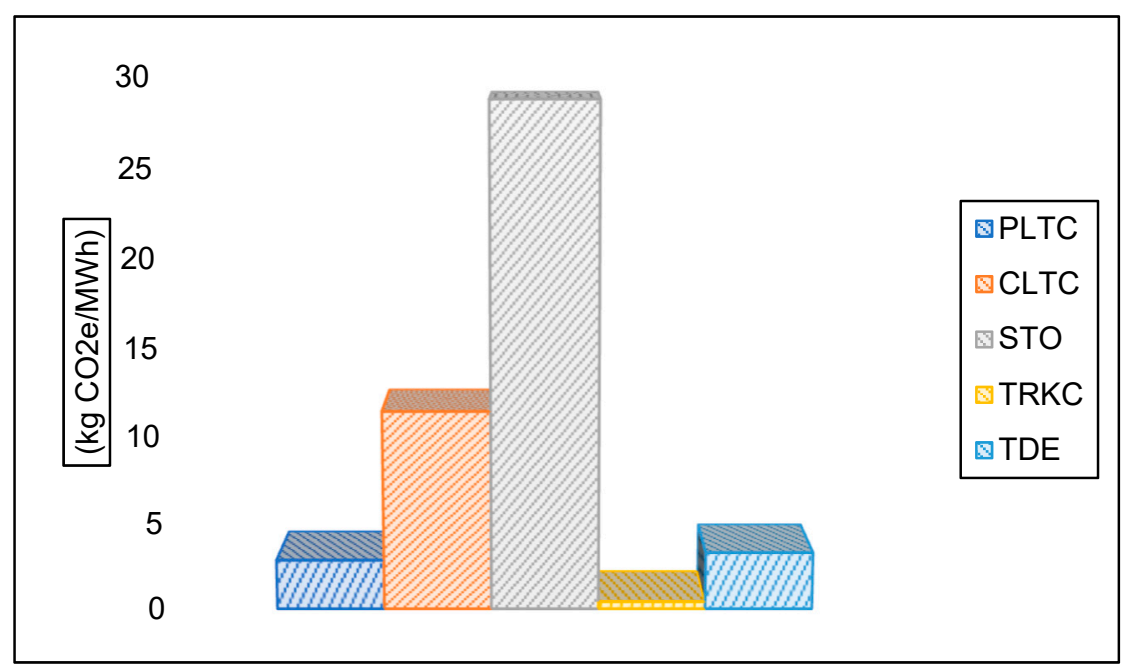

Figure 8. life cycle greenhouse gas for solar thermal power plant

Energy is captured from radiation and it is converted into heat afterward is employed for producing electrical energy within steam turbines. As with wind energy sources, the emissions linked to the solar thermal power plant are associated with the activities of manufacturing and constructing of CRE facilities. Since wind does not require extraction and transportation. Thus, considering the impact that wind onshore facilities may have on the environment the figure above shows the life cycle GHGs related to plant construction (PLTC) estimated at $2.83 \mathrm{~kg} \mathrm{CO} 2 \mathrm{e} / \mathrm{MWh}$, collector construction (CLTC) evaluated at $11.39 \mathrm{~kg} \mathrm{CO} 2 \mathrm{e} / \mathrm{MWh}$, solar thermal operation (STO) estimated at $28.7 \mathrm{~kg} \mathrm{CO} / \mathrm{MWh}$, Trunkline Construction (TRKC) amounted to $0.41 \mathrm{~kg}$ $\mathrm{CO} 2 \mathrm{e} / \mathrm{MWh}$. Lastly, as with other power generating sources presented in the above sections. At TDE stage when conveying the electricity from solar thermal to the end-users the amount of Sulphur hexafluoride realised into the air is estimated at $3.27 \mathrm{~kg} \mathrm{CO} 2 \mathrm{e} / \mathrm{MWh}$. The reason may be due to the fact it is seen as an excellent electrical insulator for high voltage.

\subsection{Environmental assessment for hydro power plant}

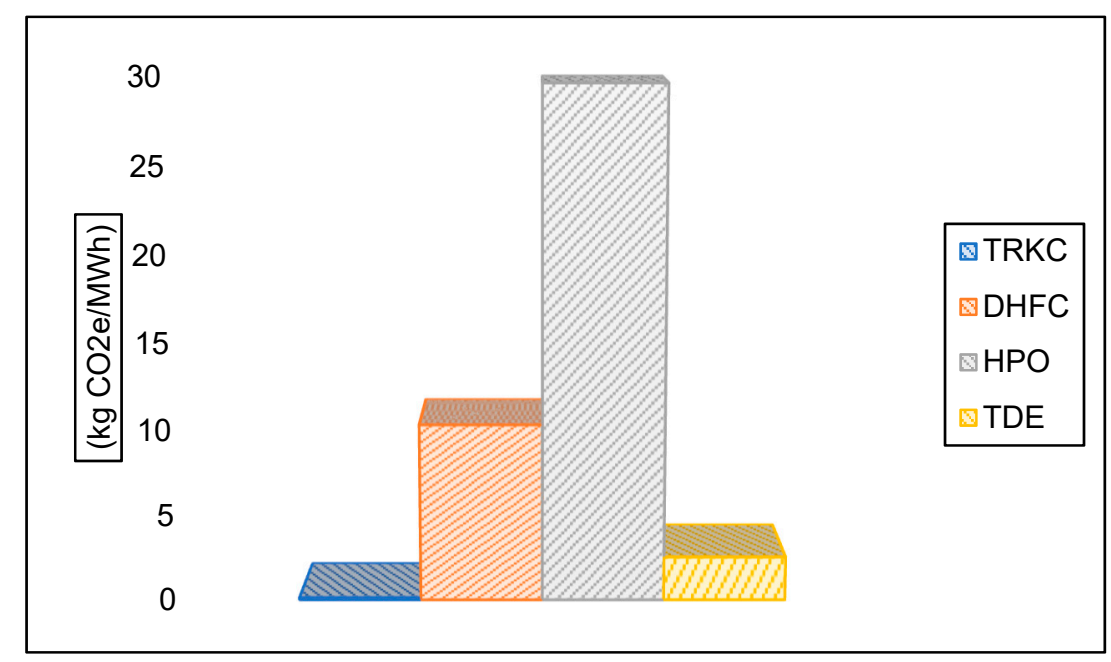

Figure 9. life cycle greenhouse gas for hydro power plant

The GHGs emissions linked to the hydro power plant are associated with the activities of manufacturing and constructing of CRE facilities. Since water does not require extraction and transportation. Thus, considering the impact that hydro facilities may have on the environment 
the figure 9 above shows the life cycle GHGs related to Trunkline Construction (TRKC) amounted to $0.119 \mathrm{~kg} \mathrm{CO} 2 \mathrm{e} / \mathrm{MWh}$, Dam and Hydropower Facility Construction (DHFC) estimated at $10.3 \mathrm{~kg} \mathrm{CO} 2 \mathrm{e} / \mathrm{MWh}$, hydro plant operation (HPO) evaluated at $29.6 \mathrm{~kg} \mathrm{CO} 2 \mathrm{e} / \mathrm{MWh}$. At TDE stage when conveying the electricity from hydro to the end-users the amount of Sulphur hexafluoride realised into the air is estimated at $2.54 \mathrm{~kg} \mathrm{CO} 2 \mathrm{e} / \mathrm{MWh}$. The reason may be due to the fact it is seen as an excellent electrical insulator for high voltage.

\subsection{Comparative environmental assessment results for different power generating plants}

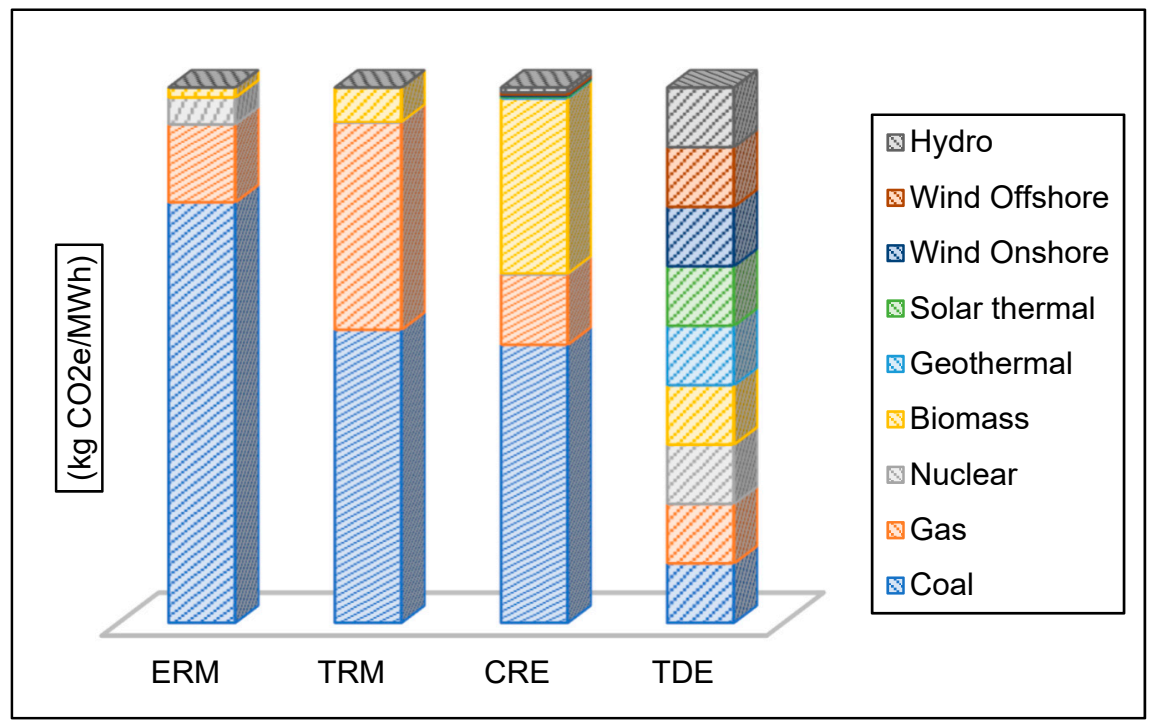

Figure 10. life cycle greenhouse gas for different power production plants

From the figure 10 above, it can be depicted the life cycle greenhouse gas grid emission factor results for various technologies. The first impression is that a significant amount of GHGs emissions for the majority of technologies are emitted during the CRE stage. For example, coal, biomass, and gas power generation plants, the core point of greenhouse gas grid emission factor is the combustion of fuel at the CRE stage. Whilst, the major point of GHGs emissions concerning hydropower, is the slow deterioration of plant deposit in the reservoir. The production of naturally-stirring carbon dioxide from geofluid is the main point of greenhouse gas emissions from geothermal energy generating source. Whereas, wind and solar energy sources are different from the technologies highlighted above since their main point of GEF is not generated from the activities associated with operation of the CRE, however, the GEF are linked to the activities related to the manufacturing of equipment and building of the CRE facility. The figure 10 also demonstrates that nuclear is the only energy generating source that has got the highest GEF for ERM than for the CRE. The reason is because the enrichment of uranium requires an important amount of energy that makes the ERM stage the main source of GEF for nuclear power plant. It was also noticed that most of renewable energy sources have the highest assortment of ambiguity in life cycle greenhouse gas emission results. This ambiguity is due to inconsistency aspect of the operation of the plant. For example, the production of electricity from wind depends on the availability and strength of the wind. Whilst, the generation of energy from solar depends on the availability of the sun. this implies that whenever the sky is cloud the amount of electricity is insignificant. Since the GEF of wind energy comprises the allotment of manufacturing and construction emissions per unit of energy generated throughout its lifespan of a wind farm. An akin assumption may be drawn up for solar energy source. 


\section{Conclusion}

Environmental assessment is a concept that has been designed to facilitate the present generation to meet their needs without compromising the ability of future generations to meet their own needs as well. Thus, this concept has drawn significant attention from various scholars, researchers and industrial practitioners around the world over the past three decades. Life Cycle Environmental Assessment (LCEA) is a widely metric used to assess the potential ecological impacts, which can be caused by electricity generating supply systems or by other systems than power production plants. However, the current LCEA model is biased and ineffective. Because, its omits factors that are increasingly contributing to the ecological degradation. The novel developed LCEA model has been tested and applied to nine power generation plants such as coal, gas, nuclear, biomass, geothermal, hydro, solar thermal, wind onshore and wind offshore. The results have demonstrated that of conventional technologies including coal, gas, and nuclear, coal energy generating source has got the highest life cycle greenhouse gas Grid Emission Factor (GEF) of $2866 \mathrm{~kg} \mathrm{CO} 2 \mathrm{e} / \mathrm{MWh}$, followed by gas with $728 \mathrm{~kg} \mathrm{CO} 2 \mathrm{e} / \mathrm{MWh}$, and nuclear has got the least GEF of $35 \mathrm{~kg} \mathrm{CO} \mathrm{e} / \mathrm{MWh}$. Whereas of renewable energy sources biomass has got the highest GEF of $1508 \mathrm{~kg} \mathrm{CO} 2 \mathrm{e} / \mathrm{MWh}$, followed by solar thermal with $46.6 \mathrm{~kg} \mathrm{CO} 2 \mathrm{e} / \mathrm{MWh}$, hydro $39 \mathrm{~kg} \mathrm{CO} 2 \mathrm{e} / \mathrm{MWh}$, wind offshore $25.25 \mathrm{~kg} \mathrm{CO} 2 \mathrm{e} / \mathrm{MWh}$, wind onshore $10.1 \mathrm{~kg} \mathrm{CO} 2 \mathrm{e} / \mathrm{MWh}$, and geothermal closes the ranking with $6.23 \mathrm{~kg} \mathrm{CO} 2 \mathrm{e} / \mathrm{MWh}$. It was depicted that the life cycle greenhouse gas grid emission factor results for various technologies. The first impression is that a significant amount of GHGs emissions for the majority of technologies are emitted during the CRE stage. For example, coal, biomass, and gas power generation plants, the core point of greenhouse gas grid emission factor is the combustion of fuel at the CRE stage. Whilst, the major point of GHGs emissions concerning hydropower, is the slow deterioration of plant deposit in the reservoir. The production of naturally-stirring carbon dioxide from geofluid is the main point of greenhouse gas emissions from geothermal energy generating source. Whereas, wind and solar energy sources are different from the technologies highlighted above since their main point of GEF is not generated from the activities associated with operation of the CRE, however, the GEF are linked to the activities related to the manufacturing of equipment and building of the CRE facility. The figure 10 also demonstrates that nuclear is the only energy generating source that has got the highest GEF for ERM than for the CRE. The reason is because the enrichment of uranium requires an important amount of energy that makes the ERM stage the main source of GEF for nuclear power plant. It was also noticed that most of renewable energy sources have the highest assortment of ambiguity in life cycle greenhouse gas emission results. This ambiguity is due to inconsistency aspect of the operation of the plant. For example, the production of electricity from wind depends on the availability and strength of the wind. Whilst, the generation of energy from solar depends on the availability of the sun. this implies that whenever the sky is cloud the amount of electricity is insignificant. Since the GEF of wind energy comprises the allotment of manufacturing and construction emissions per unit of energy generated throughout its lifespan of a wind farm. An akin assumption may be drawn up for solar energy source.

\section{References}

Abbaspour M., Monavari M., Karbassi A \& Kargari N.2011. Nuclear Power and Its Role in CO2 Emissions from the Electricity Generation Sector in Iran, Energy Sources, Part A: Recovery, Utilization, and Environmental Effects, 34:1, 43-52, DOI: $10.1080 / 15567036.2010 .483532$

Adams, B., Kennedy, A., \& Sahely, R.2005. Developing sustainability criteria for urban infrastructure systems. Journal of Civil Engineering, 32, 72-85.

Akadiri, P., Olomolaiye, P., \& Chinyio, E.2013. Multi-criteria evaluation model for the selection of sustainable materials for building projects. Automation in Construction, 30, 113-125 
Alexandru M.2014. Sustainability assessment of electricity generation technologies using weighted multi-criteria decision analysis. Energy Policy 65, 284-297

Alvaro R, Edson B, Raphael M.2015. A life cycle assessment of the Brazilian coal used for electric power generation. Journal of Cleaner Production 92,179-186

Amit B, Richard H, Paul F, William R, Nilay S, Niall M,John D, Markus K, Mohammed P, Mathieu I, Jenny J, Nigel B, Ausilio B, Corinne B, Andrew S, Jethro A. 2017. Screening and techno-economic assessment of biomass-based power generation with CCS technologies to meet 2050 CO2 targets. Applied Energy 190, 481-489

Andhra P, India K, Suresh J, Arvind K, Sunil D.2014. A life cycle environmental impact assessment of natural gas combined cycle thermal power plant in. Environmental Development 11, 162-174

Andrew P, Tania U, Andrew M.2011. Life cycle assessment of a community hydroelectric power system in rural Thailand. Renewable Energy 36, 2799-2808

Ángel G., Gonzalo G., Laurence S., Adisa A.2016. Enhanced data envelopment analysis for sustainability assessment: A novel methodology and application to electricity technologies, Computers and Chemical Engineering 90, 188-200

Annette E, Vladimir S, Tim J.2009. Assessment of sustainability indicators for renewable energy technologies. Renewable and Sustainable Energy Reviews 13, 1082-1088

Araújo M, Ribeiro F, Ferreira P,. 2013. Evaluating future scenarios for the power generation sector using a multicriteria decision analysis (MCDA) tool: the Portuguese case. Energy 2013;52:126-36

Ariaratnam, S \& Koo, D.2008. Application of a Sustainability Model for Assessing Water Main Replacement Options. Journal of Construction Engineering and Management, 134, 8, 563-574.

Arvesen A, Hertwich E. 2012. Assessing the life cycle environmental impacts of wind power: a review of present knowledge and research needs. Renewable and Sustainable Energy Reviews 16, 5994-6006

Arvesen A., Ingrid B., Bernhard M., Edgar G.2015. Life cycle assessment of transport of electricity via different voltage levels: A case study for Nord-Trøndelag county in Norway. Applied Energy 157, 144-151

Arvidsson R, Kristin F, Morgan F, Magdalena S, Sverker M. 2012. "Energy Use Indicators in Energy and Life Cycle Assessments of Biofuels: Review and Recommendations.” Journal of Cleaner Production 31, 54-61.

Ays, e, Emrah O, Ihsan K., Hameed A. 2017. Life cycle assessment (LCA) of digested sewage sludge incineration for heat and power production, Journal of Cleaner Production 142, 1684-1692

Bohm M. 2007. Capture-ready coal plants - options, technologies and economics. International journal of greenhouse gas control, 1, 113-120.

Bonou, Alexis L, Stig I.2016. Life cycle assessment of onshore and offshore wind energy-from theory to application Alexandra. Applied Energy 180, 327-337

Bridget M. Z Zeb J, Carol A. .2009.Comparison of Life Cycle Carbon Dioxide Emissions and Embodied Energy in Four Renewable Electricity Generation Technologies in New Zealand. Environ. Sci. Technol. 2009, 43, 6406-6413

Burcin A, Adisa A.2015. Life cycle environmental impacts of electricity from fossil fuels in Turkey Journal of Cleaner Production 106, 555-564

Burcin A, Adisa A.2016. Renewable electricity in Turkey: Life cycle environmental impacts. Renewable Energy 89, 649-657

Cameron M, John B, Eric S, Amberli Y, Jessica S, Tiffany Y, Shabbir H.2015. Comparative Life Cycle Assessment of a Thai Island's diesel/PV/wind hybrid. Renewable Energy 80, 85-100

Carlo S, Adriana D, Paola C, Michela G, Emma B, Paola G.2015. Life Cycle Assessment and Life Cycle Costing of a SOFC system for distributed power generation Energy Conversion and Management 100, 64-77

Carrera D, Mack A. 2012.Sustainability assessment of energy technologies via social indicators: result of a survey among European energy experts. Energy Policy; 38:1030-9.

Changqing X., Jinglan H., Jianmei C., Xiaofei H., Chen L., Xiangzhi L.2016. Is biomass energy really clean? An environmental life-cycle perspective on biomass-based electricity generation in China Journal of Cleaner Production 133, 767-776 
Chao F, Xuenong G, Yuting T, Yuansheng Z. 2014. Comparative life cycle environmental assessment of flue gas desulphurization technologies in China. Journal of Cleaner Production 68, 81-92

Cristina I, Carine L, Francesco C.2016. Life-cycle assessment of a biogas power plant with application of different climate metrics and inclusion of near-term climate forcers. Journal of Environmental Management 184, 517-527.

Dalia S, Ilona A.2014. External costs of electricity generation options in Lithuania. Renewable Energy 64, 215-224

De Feo G, Forni M, Petito F, Renno C. 2016. Life cycle assessment and economic analysis of a low concentrating photovoltaic system. Environmental Technology, 37:19, 2473-2482, DOI: 10.1080/09593330.2016.1152308

Diego G, Daniel G, Javier D.2017. Prospective life cycle assessment of the Spanish electricity production. Renewable and Sustainable Energy Reviews 75, 21-34

Diego G, Diego I, Daniel G.2017. Prospective analysis of energy security: A practical life-cycle approach focused on renewable power generation and oriented towards policy-makers Applied Energy 190, 891-901

Diego G, Diego I, Mario M, Javier D, Kari E, Arne L.2016. Integration of life-cycle indicators into energy optimisation models: the case study of power generation in Norway. Journal of Cleaner Production 112, 2693-2696

Diego G., Kari, E., Arne. L., Martin, K. 2016. The role of the discount rates in energy systems optimisation models. Renewable and Sustainable Energy Review, 59, 56-72. Available from www.sciencedirect.com

Diogo A, Ivete D, Mary L, Aldo R.2014. Life cycle assessment of the sugarcane bagasse electricity generation in Brazil. Renewable and Sustainable Energy Reviews 32, 532-547

Edgar R, Arturo M.2014. Optimizing the energy portfolio of the Mexican electricity sector by 2050 considering CO2eq emissions and Life Cycle Assessment. Energy Procedia 57, 850 - 859

Eduard C, Nicholas F., Sarah J., and Joule B. 2015. Sustainability of Rooftop Technologies in Cold Climates Comparative Life Cycle Assessment of White Roofs, Green Roofs, and Photovoltaic Panels, Journal of Industrial Ecology, DOI: 10.1111/jiec.12269

Eduard O, Antoni G, Alvaro d, Dieter B, Luisa F.2012. Comparative life cycle assessment of thermal energy storage systems for solar power plants. Renewable Energy 44, 166-173

Elvira B, Laura V, Alberto C, Sergio U.2015. Integrating life cycle assessment and emergy synthesis for the evaluation of a dry steam geothermal power plant in Italy Energy 86, 476-487

Elvira B, Pier P, Sergio U.2012. Assessing the environmental performance and sustainability of bioenergy production in Sweden: A life cycle assessment perspective. Energy 37, 69-78

Ernesto L, Elena R, Henri S, Osvaldo R, Steven De M, Dewulf J. 2016. A comparative assessment of anaerobic digestion power plants as alternative to lagoons for vinasse treatment: life cycle assessment and exergy analysis. Journal of Cleaner Production 113, 459-471.

Fatemeh D, Majid S, Khosro A.2017. A well to wire LCA model development and sensitivity analysis for carbon footprint of combined cycle power plants in Iranian electricity network, International Journal of Green Energy, 14:5, 499-508, DOI: 10.1080/15435075.2017.1279618

Felix M; Gheewala S.2012. Environmental assessment of electricity production in Tanzania. Energy for Sustainable Development, 16, 439-447.

Francisca F, Carlos P, Mercedes R.2016. Life cycle assessment of biodiesel in Spain: Comparing the environmental sustainability of Spanish production versus Argentinean imports. Energy for Sustainable Development 33, 36-52

Fthenakis V, Kim HC. 2007. Greenhouse-gas emissions from solar electric- and nuclear power: a life-cycle study. Energy Policy; 35:2549-57

Gagnon, L., Belanger, C., \& Uchiyama, Y. 2002. Life-cycle assessment of electricity generation options: The status of research in year 2001. Energy Policy, vol. 30, no. 14, 1267-1278. 